\title{
Are urban spaces queer-friendly places? How geographic context shapes support for LGBT rights
}

\author{
Jack Thompson ${ }^{1}$ \\ ${ }^{1}$ Department of Politics, University of Exeter
}

February 14, 2022

\begin{abstract}
The US is geographically divided on LGBT rights. Urban contexts represent environments where individuals are generally more supportive of LGBT rights, while support is lower in nonurban contexts. Despite these differences, there is a paucity of research on why individuals in urban contexts are more supportive of LGBT rights. Using data from the General Social Survey (GSS), the Public Religion Research Institute (PRRI), and the Cooperative Congressional Election Study (CCES), this paper explores the relationship between urbanicity and support for LGBT rights. Results demonstrate than urban residents exhibit higher levels of support for LGBT rights than nonurban residents. In testing potential mechanisms that explain support for LGBT rights in urban contexts, multilevel analyses indicate that the metro-level population density of LGBT individuals conditions the relationship between urban residence and support for LGBT rights. I also find mixed evidence for the effects of geographic sorting on support for LGBT rights, thus eliminating the possibility that individuals with homopositive select into large cities. The paper highlights the important role that urban environments play in shaping public support for LGBT rights.
\end{abstract}

Keywords: Geographic context; LGBT rights; intergroup contact; public opinion 


\section{Introduction}

In recent years, scholars have paid increasing attention to the role of geographic divides in American political behavior (Gimpel et al. 2020, Fiorina \& Abrams 2008, Munis 2021. Scala \& Johnson 2017). In addition to these studies, contemporary work attests to how urban-rural divides shape public opinion towards a variety of groups in US society, including racial minorities (Curtis 2021), immigrants (Maxwell 2019), and scientists (lunz Trujillo 2022). While much scholarship underscores the relevance of urban-rural divides in shaping attitudes towards various groups in US society, there is a noteworthy paucity of studies attesting to the impact of geographic polarization on attitudes towards those with non-heteronormative and non-cisgender identities. These omissions are somewhat surprising. Within the last two decades, the US has seen a dramatic expansion of policy initiatives aimed at remedying much of the historical persecution of individuals who identify as lesbian, gay, bisexual, or transgender (LGBT). Despite the many policy gains made in recent years, debates over the extent of protections for LGBT individuals remain highly salient in contemporary US politics. For instance, a new record was set in 2021 for the filing of anti-transgender legislation, with more than 110 bills put forward by legislators in at least 37 states (Atkins 2021).

A desire to understand various the concomitants of support for/opposition LGBT rights has given rise to a burgeoning literature within the field of American public opinion. Consequently, attitudinal polarization on LGBT rights is known to take on many forms, whether it be between parties, disparate political ideologies, age cohorts, genders, education levels, or other relevant demographic characteristics(Castle|2019, Olson, Cadge \& Harrison|2006, Sherkat, Vries \& Creek|2010, Sherkat, Powell-Williams, Maddox \& Vries 2011). Considering this vast literature, it is noteworthy how we know surprisingly little on the impact of structural factors - and specifically, the role of urbanicity - in shaping support for LGBT rights. Still, the limited number of studies that contain a control for urbanicity provide some indication that public attitudes towards the LGBT community 
are divided according to the types of communities that Americans live in. Individuals living in urban environments are more likely to be supportive of LGBT rights. For instance, studies find that urban residence is associated with higher support for same-sex marriage (Baunach 2012). By contrast, outside large cities - and especially in exurban and rural areas - individuals are more likely to oppose LGBT rights. Indeed, those living in rural areas are more likely to oppose same-sex marriage (Smith, DeSantis \& Kassel 2006. Sherkat, Vries \& Creek 2010), and are less likely to oppose permitting the denial of service to LGBT individuals (Flores et al. 2020).

To answer the question why individuals in urban environments are more likely to support I draw on scholarship concerning geographic differences in attitudes towards marginalized groups. These studies posits that something about the experience of living in urban environments makes individuals more likely to adopt prosocial attitudes towards LGBT identifying individuals. In particular, urban residents are more likely live in high population density environments, thus facilitating greater opportunities for positive intergroup contact, which might make them more supportive of LGBT rights. To further quantify the impact of urban residence on support for LGBT rights relationship, I attempt to eliminate the possibility of reverse causality by drawing on scholarship on the relationship between political attitudes and individual moving preferences. This literature argues that individuals select into certain communities according to their political beliefs (Cho et al. 2013). In this way, individuals with homopositive attitudes might select into cities, which usually represent welcoming and tolerant environments for the LGBT community. Conversely, those with homonegative attitudes might select into exurban/rural areas, which are seen as less tolerant and open spaces for individuals who identify as LGBT.

To explore geographic divides on LGBT rights, I analyze data from the General Social Survey (GSS), the Public Religion Research Institute (PRRI), and the Cooperative Congressional Election Study (CCES). Overall, the results provide strong evidence in support 
of the claim that urban residence is conducive of support for LGBT rights. Cross sectional analyses demonstrate a consistent relationship between residence in a metro area and higher levels of support for a litany of LGBT-related policy preferences. Multilevel models find that support for LGBT rights is highest in metro areas of the US with the greatest concentration of LGBT individuals, lending weight to the intergroup contact hypothesis. Analyses also indicate that individuals who have lifelong exposure to urban environment exhibit higher support LGBT rights than those who do not. More importantly, tests for within-subject attitudinal changes using panel data indicate that moving to an urban area between 2010 and 2014 is associated with an increase in support for LGBT rights. Panel data are also able to eliminate the possibility of reverse causality through the impact of geographic sorting. Specifically, I find that prior support/opposition for LGBT rights imparts no influence on an individual's decision to move to/from urban areas of the US.

The paper proceeds as follows. I begin by delineating my hypotheses concerning the relationship between urbanicity and higher support for LGBT rights. Next, I outline the sources of data and methods used to empirically test my set of hypotheses. After outlining data and methods, I present my main findings using cross-sectional and longitudinal data. I conclude with a discussion of my findings, including their implications for the future study of public opinion on LGBT rights, as well as their contribution to the broader scholarship concerning the geographic polarization of political attitudes.

\section{Hypotheses}

While there is an understanding of the many socio-political and demographic concomitants of support for LGBT rights $\left.\right|_{1} ^{1}$ there is comparatively little evidence on the role of urban environments in shaping support for LGBT rights in the US context. Support

\footnotetext{
${ }^{1} 1$ Research suggests individuals who support LGBT rights tend to affiliate with the Democratic party, are politically liberal, are younger, identify as female, have at least some college experience, and are nonreligious (Castle 2019. Olson, Cadge \& Harrison|2006. Sherkat, Vries \& Creek|2010, Sherkat, Powell-Williams, Maddox \& Vries 2011).
} 
for LGBT rights is known to vary across the many socio-political and demographic factors that influence public attitudes (Lewis et al. 2017). However, little attention has been paid to variation in support for LGBT rights across the urban-rural interface. Though some contemporary studies include a dichotomous measure of subjective urbanicity (Flores et al. 2020) $)^{2}$ many do not include one at all (Cao \& Gurcay 2021, Castle 2019, Flores 2015, Flores, Haider-Markel, Lewis, Miller, Tadlock \& Taylor 2018, Jones, Brewer, Young, Lambe \& Hoffman 2018, Lewis, Tadlock, Flores, Haider-Markel, Miller \& Taylor 2021). These studies do not provide us with a nuanced approximation of whether individuals living urban environments exhibit higher support for LGBT rights than those in nonurban environments. Consequently, there is a need to better understand the role of urbanicity in shaping support for LGBT rights. The limited evidence in from extant literature suggests that we might observe a general, positive relationship between residence in urban environments and support for LGBT rights (Flores et al. 2020). My first hypotheses therefore provides a direct test of this relationship:

H1: Support for LGBT rights is higher in urban environments than nonurban environments.

My next hypotheses explores why support for LGBT rights is higher in urban environments. Scholarship on the relationship between intergroup contact and public opinion towards the LGBT community offers a useful frame for understanding why support for LGBT rights might be higher in urban environments than nonurban environments. It has long been established that contact between groups reduces prejudice (Allport 1954, Davies et al.2011), and the relationship between individual-level intergroup contact and support for LGBT rights is, likewise, much documented (Garner|2013, Herek \& Capitanio

\footnotetext{
${ }^{2}$ That is, respondents' approximations of whether they live in an urban or rural area.
} 
1996, Tadlock, Flores, Haider-Markel, Lewis, Miller \& Taylor 2017). 3

Studies find that the relationship between intergroup contact and support for LGBT rights holds at the contextual level as well as the individual level (Barth et al. 2009, Earle et al. 2021, MacInnis et al. 2017). While these works find that contextual effects do shape support for LGBT rights, discussion of role of specific geographic contexts (for instance urban environments) have been largely overlooked. Despite these omissions, there are nonetheless reasons for expecting that the relationship between intergroup contact (i.e., cis/straight individuals' interactions with LGBT individuals) and support for LGBT rights is especially salient for those living in urban environments. This expectation would be consistent with much of the work on "geographies of encounter" - a body of scholarship that is primarily interested in the relationships between the diversity of social networks, urban environments, and prejudice (Valentine 2008, Wilson|2011, 2013, 2017).

Though much of this research has focused on how encounters between individuals of different ethnic and racial backgrounds within large cities lower prejudice, the mechanism is likely the same in the case of relations between individuals with varying sexual and gender identities in urban environments. Urban environments typically have higher densities of minority populations than nonurban environments, which will inevitably lead to greater interaction across a wider range of shared urban spaces (Powers et al. 2021). This process of being forced to share space may lead individuals to become more accepting and tolerant of minority populations as a basic coping mechanism for dealing with everyday life in the city $\left.\right|^{4}$ As is the case with other minority populations, the LGBT population in the US is not evenly distributed across urban-rural environments. Rather,

\footnotetext{
${ }^{3}$ In addition to these broad relationships, contact with LGBT individuals varies between family members, to close friends, to acquaintances, meaning that quality of contact shapes the degree to which individuals might support LGBT rights. For instance, Dyck \& Pearson-Merkowitz (2014) find that contact resulting from close friends and family members who identities as LGBT was associated with higher support for same-sex marriage than contact through LGBT-identifying acquaintances and coworkers.

${ }^{4}$ Still, a pervasive critique of cosmopolitan urbanism is that some works overromanticize encounters in urban contexts, leading to a potentially naive assumption that contact with outgroups necessarily translates into tolerance (Valentine 2008).
} 
LGBT individuals are clustered within large metro areas of the US (Conron et al. 2020).5 It follows that a high concentration of LGBT individuals within a geographically bounded space ought to facilitate greater opportunities for intergroup contact between those with different sexual and gender identities, leading to higher levels of tolerance which may translate into support for LGBT rights. These developments lead me to state my second hypothesis as:

H2: Support for LGBT rights is higher in urban environments because of greater opportunities for intergroup contact with LGBT individuals.

Next, the logic of my previous hypotheses generates further hypotheses that distinguish between two types of urban residents: individuals who moved to urban environments, and individuals who have spent their entire lives living in urban environments. If contextual effects shape the attitudes of individuals who move to urban environments, de demimis, then we should expect support for LGBT rights to increase after moving to urban environments, while support for LGBT rights does not change among individuals who do not move. This comparison accounts for the fact that attitudes may change over time for a multitude of reasons, but that the effects of geographic context may be isolated by comparing those who move against those who do not. Contextual-level effects may also shape the attitudes of individuals who spend their entire lives in certain environments through long-term socialization on attitudes towards LGBT individuals that begin during early development (Agnew et al. 1993, Poteat 2007). If these observations hold true, then we should also expect support for LGBT rights to be higher among individuals who have spent their entire lives living in urban environments than among those who live in nonurban geographic contexts. My next hypotheses are thus stated as:

\footnotetext{
${ }^{5} 88.3$ percent of individuals who identify as LGBT in the United States live in urban area (Badgett et al.
} 2019). 
H3a: Moving to urban environments makes individuals more supportive of LGBT rights. H3b: Spending one's entire life in an urban environment makes individuals more supportive of LGBT rights.

Lastly, even if we find evidence in favor of H1-H3, it is necessary to test for the possibility of reverse causality through the impact of homopositive and homonegative attitudes on preferences for moving to and leaving urban environments. In other words, individuals might select into different geographic contexts according to whether they support or oppose LGBT rights. Consistent with this possibility, much scholarship points to an ongoing sociopolitical sort in the US (Bishop 2009, Lang \& Pearson-Merkowitz 2015). One consequence of this ongoing sort is that individuals increasingly select into different geographic contexts according to their sociopolitical beliefs (Cho et al.2013). In the context of LGBT rights, urban environments are known for their higher concentration of LGBT individuals (Badgett et al. 2019), as well as for being sites of openness and tolerance for the LGBT community ${ }^{6}$ As such, those who favor environments where individuals can be openly LGBT without fear of social stigma might be more attracted to urban contexts. By contrast, the open and tolerant environment for LGBT individuals found in urban contexts may engender those who oppose LGBT rights to leave such environments. In this way, urban-rural divides on support for LGBT rights might be reflective of geographic sorting according to attitudes on LGBT rights.

Nevertheless, there are reasons for expecting that claims about the impact of political attitudes on moving preferences are overstated. For instance, recent evidence suggests

\footnotetext{
${ }^{6}$ LGBT individuals from exurban and suburban areas tend to select into large cities, where they are better-placed to accumulate power resources (Annes \& Redlin 2012, Weston 1995). The various political and social incentives from urban living also allows LGBT individuals to develop visibly-queer institutions that would not otherwise by viable in nonurban contexts. Still, this is not to say that LGBT individuals do not encounter discrimination in urban contexts. For instance, many analyses note the exclusions generated by "gay villages" in large cities, paying attention to how Whiteness and masculinity facilitate a gay urban politics of belonging that can establish within-group social hierarchies. For instance, racial hierarchies have been observed in the gay villages of Chicago, Manhattan, San Francisco (Ghaziani 2015, Rosenberg 2016. Stewart-Winter 2015).
} 
that, while partisans differ in their residential preferences, they do not migrate to politically distinct communities as a consequence of their sociopolitical beliefs (Mummolo \& Nall 2017). Similarly, in an analysis of the impact of partisan attitudes on moving preferences, Martin \& Webster (2020) find that the estimated level of partisan bias in moving choices were on the order of five times too small to explain current levels of geographic polarization in the US. Given these studies, if we find a pattern of insignificant relationships between homopositive and homonegative attitudes and Americans' moving preferences to and from large cities, this can be taken as further evidence that urban environments shape support for LGBT rights (as opposed to the inverse being true). These developments lead me to state my final hypotheses as:

H4a: Pro-LGBT attitudes do not influence whether individuals move to large cities.

H4b: Anti-LGBT attitudes do not influence whether individuals move out of large cities.

\section{Data and Methods}

\subsection{Data}

To test these hypotheses, I leverage three sources of data. My first source of data is the University of Chicago/NORC General Social Survey (GSS) over a period spanning 2000 to 2018. The GSS is a biannual, nationally representative survey of US adults, and is drawn using an area-based probability design. The GSS contains measures of public support for LGBT rights, as well as measure of past and present urbanicity. The survey is also known for its consistency of response categories for repeated questions, allowing me to pool multiple waves of data to leverage a large sample size.

My second source of data is a survey conducted by the Public Religion Research Institute (PRRI) in April 2019. The 2019 PRRI survey is composed of a nationally representative sample of $\mathrm{N}=1,100$ adults living in any of the 48 contiguous US states, as well 
as Alaska or Hawaii. The sample was collected using stratified, single-stage random digit dialing (RDD) of landline telephone households and randomly generated cell phone numbers. Usefully, the survey includes measures gauging support for a wide variety of policies that affect LGBT individuals.

My third source of data is the Cooperative Congressional Election Study (CCES). For cross sectional analyses, I use two respective CCES datasets. First, the 2020 CES is a nationally-representative online-based survey of $N=61,563$ adults living in any of the 48 contiguous US states, as well Alaska or Hawaii. The survey was administered by the polling company YouGov, and consisted of a 20-minute pre-election wave fielded in October 2020, and a 10-minute post-election wave fielded in November 2020. Second, 2016 CCES is a nationally-representative, online-based survey of adults living in any of the 48 contiguous US states, as well as Alaska or Hawaii $(\mathrm{N}=64,000)$. Respondents were interviewed in a pre-election wave (October 2016), and again in a post-election wave (November 2016).

Data are also taken from the CCES Panel Study. The CCES Panel Study is an online based nationally representative panel. Panelists were first interviewed for the 2010 midterm elections, and then again in the 2012 presidential election and the 2014 midterm elections. Importantly, panel data allow me to observe support for LGBT rights as individuals move to and from large metro areas of the US. This is necessary for testing whether moving to urban environments increases support for LGBT rights, and would not be possible with cross-sectional data. There are three waves in the CCES panel (2010, 2012 and 2014). However, I analyze a four-year period (2010-2014) as opposed to a twoyear period (e.g., 2010-2012, 2012-2014). Analyzing a longer period of time to measure within-subjects changes is beneficial, as it increases the number of respondents who are likely to have moved to and from a large metro area of the US between panel waves. Altogether, the 2010-2014 CCES Panel Study interviewed N = 9,500 respondents across both waves. 


\subsection{Measures}

\subsubsection{Dependent Measures}

My dependent measure is support for LGBT rights. The pooled GSS data contains a variety of measures gauging support for LGBT-related policy issues. For same-sex marriage, the GSS asks "do you agree or disagree: homosexual couples should have the right to marry one another," with possible responses ranging between $1=$ "strongly agree," to 5 = "strongly disagree.". The GSS also asks respondents whether sexual relations between two adults of the same sex is wrong, with possible responses ranging between $1=$ "always wrong," to $4=$ "not wrong at all." Beyond the two ordinal measures, the GSS also contains three dichotomous items asking i) whether a homosexual individual should be allowed to speak before a public audience $(1=$ "allowed," $0=$ "not allowed), ii), whether a homosexual book should be removed from a public library $(1=$ "removed," $0=$ "not removed"), and iii) whether a homosexual individual should be allowed to teach in a college or university $(1=$ "allowed," $0=$ "not allowed"). For consistent interpretation of effects across measures, I dichotomize items one $(1=$ "agree," $0=$ "neither agree or disagree/disagree"), and two $(1=$ "same sex relations not wrong at all" $0=$ "same sex relations sometimes/almost always/always wrong).

The 2019 PRRI survey contains seven items that gauge levels of public support/opposition to LGBT rights: i) whether respondents support same-sex marriage, ii) whether respondents support allowing small business owner to refuse to provide products or services to gay and lesbian people on religious grounds, iii) whether respondents support laws that would protect LGBT individuals from discrimination, jobs, and housing, iv) whether respondents support laws that require transgender individuals to use bathrooms that correspond to their sex at birth rather than their current gender identity, v) whether respondents support allowing transgender individuals to serve in the US military, vi) whether respondents support allowing licensed professionals (doctors, lawyers, etc.) to refuse to 
provide services to LGBT individuals, if doing so violates their religious beliefs, and vii) whether respondents support allowing religiously affiliated agencies that receive federal funding to refuse to place children with qualified gay and lesbian couples. $]^{7}$ To aid in substantive interpretation of effects, items are again dichotomized to indicate either support for/opposition to each policy measure.

In the $2020 \mathrm{CES}$, I use a question gauging opposition to the ban on transgender individuals serving in the US military ( 1 = "oppose," 0 = "support"). In the 2010-2014 CCES Panel Study and the 2016 CCES, I use a question gauging respondents' support for same sex marriage. Both datasets include a dichotomous item that asks whether a respondent supports or opposes same sex marriage ( 1 = "support," 0 = "oppose").

\subsubsection{Urbanicity}

Following the recommendations of Nemerever \& Rogers (2021), I measure urbanicity by drawing on multiple urban-rural classification schemes. First, the GSS measures urbanicity using a six-point categorical item that measures place as a function of proximity to standard metropolitan statistical areas (SMSAs). This designation ranges between $1=$ "12 largest SMSAs," to 6 = "other rural." To measure urbanicity in the 2019 PRRI survey, I rely on a five-point categorical measure that indicates whether a metro or non metro area of the US $(1=$ "metro," $0=$ "nonmetro"). Finally, to measure urbanicity in the CCES data, I utilize rural urban continuum codes (RUCC) provided by the US Department of Agriculture's Economic Research Service (ERS). The RUCC is a 9-point measure that categorically indicates the urbanicity of areas based on a number of factors, including the population size of their metro area, degree of urbanization, and adjacency to a metro area, and ranges from $1=$ "metro area with one million inhabitants or more," to $9=$ "nonadjacent metro area with less than 2,500 inhabitants." In section A1 of the SI file, I provide weighted estimates of the distribution of respondents across these various classification

\footnotetext{
${ }^{7}$ Items two, four, six, and seven are reverse coded in order to signify opposition to anti-LGBT policies.
} 
schemes.

\subsubsection{Intergroup Contact}

An important feature of the 2020 CCES is that respondents were "geocoded" 8 according to the metro area where they live. This allows me to leverage contextual level data on the LGBT population in large metro areas of the US. I leverage estimates on the LGBT population at the metro level using data from the Williams Institute (Conron et al. 2020). The Williams Institute estimates facilitate data on the percentage of the LGBT population among the 55 largest metro areas of the US. The range of these estimates runs from 3.3 percent (e.g., Raleigh, NC, or Pittsburgh, PA) to 6.7 percent (San Francisco, CA).

\subsection{Covariates}

Lastly, models control for a number of socio-political and demographic covariates, including ideology, 9 , race (dummy variables for "Black, non-Hispanic," "Hispanic," and "other race, non-Hispanic," with "White, non-Hispanic" serving as the base category), age (in years), gender (females coded as 1 and males as 0), LGBT identity ${ }^{10}$ education, and religion (nonreligious individuals coded as 1 and the religious individuals coded as $0)$.

\footnotetext{
${ }^{8}$ That is, each respondent has an identifier variable indicating which core-based statistical area (CBSA) where they reside.

${ }^{9}$ In the 2019 PRRI survey and the 2010-2014 CCES Panel Study, ideology is measured using a 5-point scale $(1=$ "very conservative", to $5=$ "very liberal"). In the 2016 CCES and the GSS pooled datasets, ideology is measured using a 7-point scale ( $1=$ "extremely conservative," to $7=$ "extremely liberal").

${ }^{10}$ Inclusion and measurement of respondent sexual orientation and gender identity are known to be somewhat inconsistent across surveys. Rather than including an explicit measure of identity, the GSS asks "have your sex partners in the last 12 months been exclusively male, both male and female, or exclusively female?" Using this item, I code respondents who reported having a same-sex sex partner as either lesbian, gay, or bisexual (LGB) $(1=$ "LGB", $0=$ "straight"). The 2019 PRRI contains a measure asking individuals if they identify as lesbian, gay bisexual, or transgender ( $1=$ "LGBT", $0=$ "cis/straight"). While the 20102014 CCES panel study does not ask about sexual orientation or gender identity at all, the 2016 and 2020 datasets contain two items asking respondents to indicate their sexual orientation, as well as whether they are transgender. With these two items, I create a categorical measure of LGBT identity coding respondents as either 1 = "cis/straight," 2 = "LGBT," and 3 = "nondisclosed," with the final category composed of respondents who answered "prefer not to say".
} 


\section{Results}

\subsection{Variation Across the Urban-Rural Divide}

I begin by analyzing data from the GSS to get an approximation of the relationship between geographic context and support for LGBT rights. Figure 1 graphs the predicted level of support for LGBT rights across geographic categories. As expected, support for LGBT rights is consistently higher in urban areas than nonurban areas. There is a statistically significant $(p<.05)$ gap in support for LGBT rights between residents in the 12

Figure 1: Support for LGBT Rights by Geographic Context
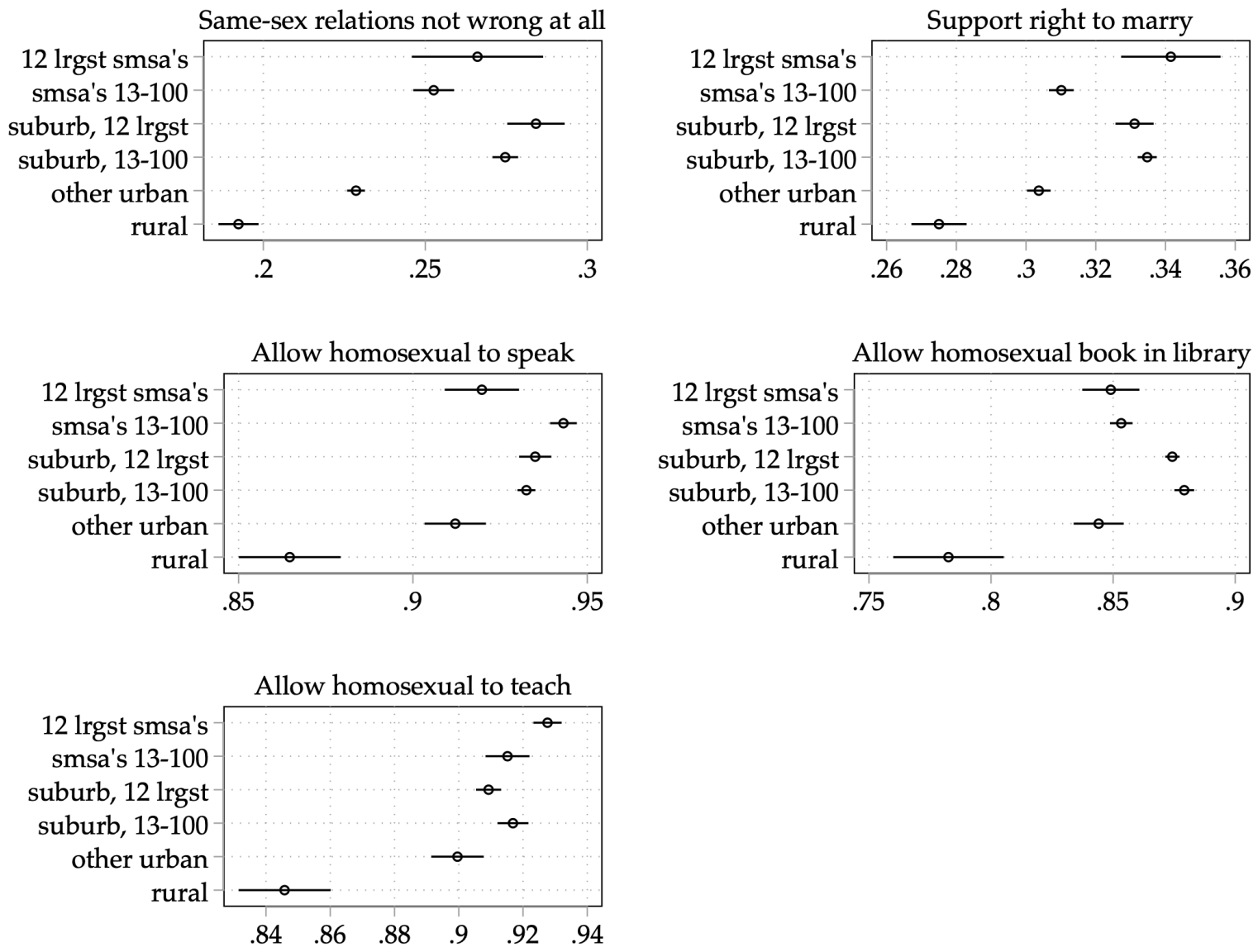

Notes: Points represent the predicted level of support for each policy. The capped lines are 95 percent confidence intervals. Predicted probabilities calculated by holding all other variables constant or at their respective mean values. Full estimates presented in section C1 of the SI file. 
largest smsa's of the US and rural residents when it comes to the belief that relations between consenting adults of the same sex are "not wrong at all" (7 points), support for the right of gay and lesbian individuals to marry (7 points), allowing a homosexual individual to make a speech in their community (5 points), allowing a homosexual book in a library (6 points), and allowing a homosexual individual to teach (8 points). In sum, the results from Figure 1 support the claim that support for LGBT rights is higher in urban environments than it is in nonurban environments (H1).

I replicate these results using data from the 2019 PRRI. While the PRRI contains fewer respondents than the GSS, the survey contains a variety of additional measures gauging support for policies that define much of contemporary debate on LGBT rights (for instance, bathroom bills and ban on transgender individuals serving in the US military). Figure 2 graphs the predicted level of support for LGBT rights according to whether respondents live in a metro or nonmetro area of the US. In a similar pattern of results to those using the GSS data, the gap in support for LGBT rights between residents of metro areas and nonmetro areas is statistically significant across a range of measures. Relative to those residing in nonmetro areas of the US, residents of non-metro areas are more likely to support the right to marry (7 points), more likely to oppose allowing businesses to refuse service to LGBT individuals on religious grounds (7 points), more supportive of laws protecting LGBT individuals against discrimination (12 points), more likely to oppose bathroom bills (4 points), more likely to oppose a ban on transgender individuals serving in the US military ( 3 points), and are more likely to oppose a ban on gay couples adopting children (5 points). The results from the 2019 PRRI thus provide further evidence of the relationship between urban environments and support for LGBT rights. 
Figure 2: Replication with 2019 PRRI
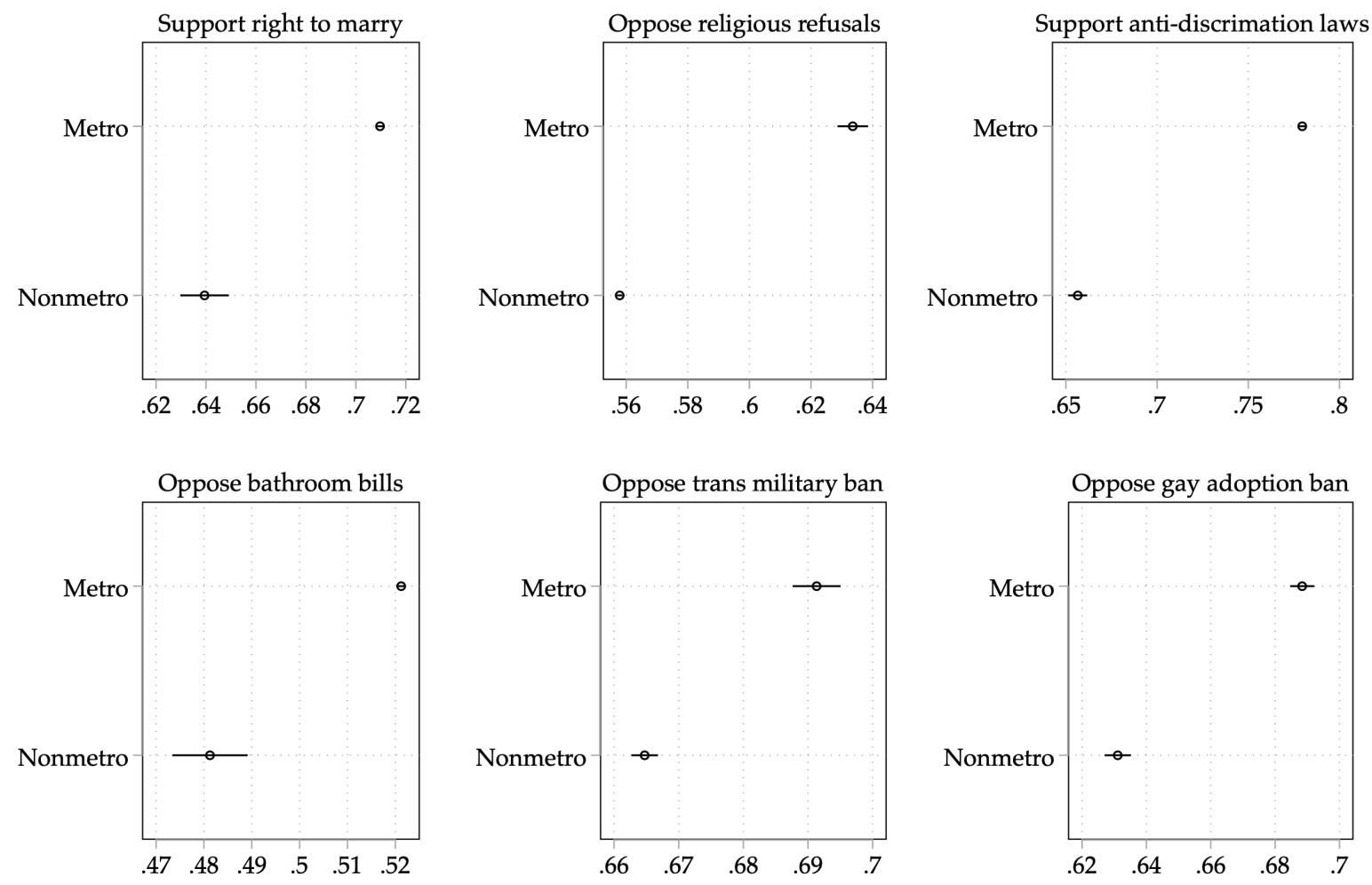

Notes: Points represent the predicted level of support/opposition to each policy. The capped lines are 95 percent confidence intervals. Predicted probabilities calculated by holding all other variables constant or at their respective mean values. Full estimates presented in section $\mathbf{C} 2$ of the SI file.

\subsection{Variation Across Large Cities}

Next, my argument underpinning $\mathbf{H} \mathbf{2}$ draws a link between urban contexts and the dense clustering of LGBT individuals within such environments (Conron et al. 2020), positing that increased proximity to more LGBT individuals will engender higher support for LGBT rights within America's largest cities. Should support for LGBT rights in large metro areas of the US be a result of close proximity to LGBT individuals, we would expect there to be variation in support for LGBT rights in metro areas with varying LGBT population sizes. In other words, if increased support for LGBT rights is the result of contact with LGBT individuals that takes place in specific geographic locales where the 
potential for intergroup contact and positive interaction is likely to be the highest, then we would expect support for LGBT rights to be significantly higher in metro areas where the clustering of LGBT individuals is the greatest.

Relying on the metro-level density of the LGBT population as an instrumental measure of intergroup contact, I estimate a multilevel model accounting for the fact that respondents from the 2020 CES are nested within metro areas of the US. Figure 3 graphs the estimated level of opposition to a proposed ban on transgender individuals serving in the US military across varying levels of LGBT population density in the 55 largest metro areas of the US. As evidenced by Figure 3, intergroup contact matters when it comes to

Figure 3: Opposition to Transgender Military Ban, Conditioned by LGBT Population Density

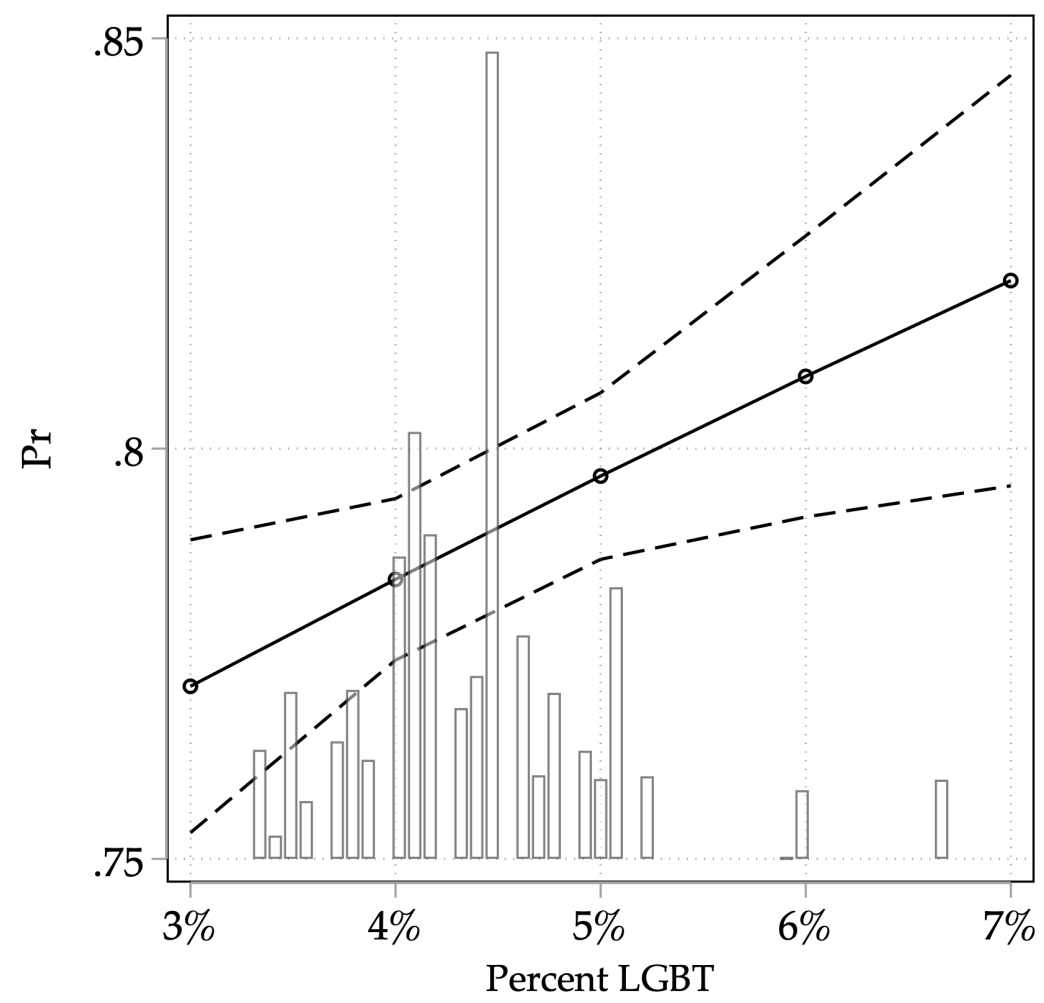

Notes: Points represent the predicted level of opposition to a proposed ban on transgender individuals serving in the US military, by the metro-level LGBT population density. The dashed lines are 95 percent confidence intervals. Predicted probabilities calculated by holding all other variables constant or at their respective mean values. Sample limited to respondents living in the 55 largest metro areas of the US. Full estimates presented in section $\mathbf{E}$ of the $\mathbf{S I}$ file. 
explaining variation in support for LGBT rights within America's largest cities. Among the 55 largest cities of the US, increases in the percentage of LGBT population produce significant increases in opposition to a ban on transgender individuals serving in the US military. In those cities where LGBT identifying individuals compose just 3 percent of the metro-level population, the estimated level of opposition to the transgender military ban is 77 points. By contrast, in cities where LGBT identifying individuals compose 7 percent of the metro-level population, the estimated level of opposition is 82 points. Therefore, increases in the density of the LGBT population within the 55 largest metro areas of the US are associated with a 5-point increase in the probability of opposing a ban on transgender individuals from serving in the US military $(p<.001)$. In sum, these findings can be interpreted as evidential support for the argument that support for LGBT rights is higher in urban environments because of the opportunity for greater contact with LGBT individuals (H2).

An alternate mechanism shaping the relationship between urbanicity and support for LGBT rights is the composition of urban environments themselves. In other words, urbanicity might be conducive of higher support for LGBT rights because of the characteristics of individuals who reside in large cities. Descriptive statistics on sociopolitical attitudes and demographic characteristics by geographic context confirm that residents of metro areas with a population greater than 1 million tend to be more politically liberal and better-educated than those in other contexts (See section B2 of the SI file ). To explore whether these differences can account for geographic differences in support for LGBT rights, I estimate a series of models. Consistent with the approach of Kelly \& Lobao (2019), I employ probit models that stagger in blocks of conceptual independent variables (sociopolitical attitudes, social statuses demographic characteristics, work factors, and sociocultural beliefs). If compositional effects do explain support for LGBT rights in large metro areas of the US, all else being equal, then the coefficient for residence in the largest metro areas of the US should approach zero and no longer be significant after the in- 
clusion of the controls. Models 2,3,4, 5, and 6 in Table D.1 indicate that the coefficient residence in the largest metro areas of the US is reduced by around 80 percent when compared to model 1 without any controls. Still, the metro $1 \mathrm{M}+$ coefficient retains it's statistical significance $(p<.05)$ in models 2 through 6 , indicating that geographic variation in support for LGBT rights exists even after accounting for relevant variables.

\subsection{Does Moving to Urban Areas Increase Support for LGBT Rights?}

To test whether moving to urban areas shapes support for LGBT rights (H3a), I leverage data from the 2010-2014 CCES Panel Study. Importantly, panel data allow me to measures within-subject changes in support for LGBT rights, meaning that I am able to compare the time trend attitudes of individuals who move to and from large metro areas of the US. The panel design compares an individuals change in large metro area residence to movement in that individuals opposition to a proposed Federal Marriage Amendment (FMA) between 2010 and 2014. In this model, moved to metro, 1M+ is equal to 1 if an in-

dividual moves to a metro area with a population greater than 1 million people, and 0 if otherwise; while left metro, $1 M+$ is equal to 1 if an individual moves away from a metro area with a population greater than 1 million people, and 0 if otherwise. The dependent variable is a lagged measure of an individual's opposition to a proposed FMA (between 2010 and 2014).

Figure 4 graphs the predicted change in the level of opposition to a proposed FMA by whether an individual either moved to or left a metro area with a population greater than 1 million people between 2010 and 2014. Predicted probabilities to the right of the x-axis indicate that moving is associated with greater opposition to a proposed FMA over time, while predicted probabilities to the left of the x-axis indicate the inverse. As evidenced by Figure 4, moving to a metro area with a population of more than 1 million people between 2010 and 2014 is associated with an 8-point increase in the predicted probability that an individual will oppose a proposed FMA. By contrast, moving out a metro area 
Figure 4: Opposition to Federal Marriage Amendment as Individuals Move to-and-from Large Metro Areas of US

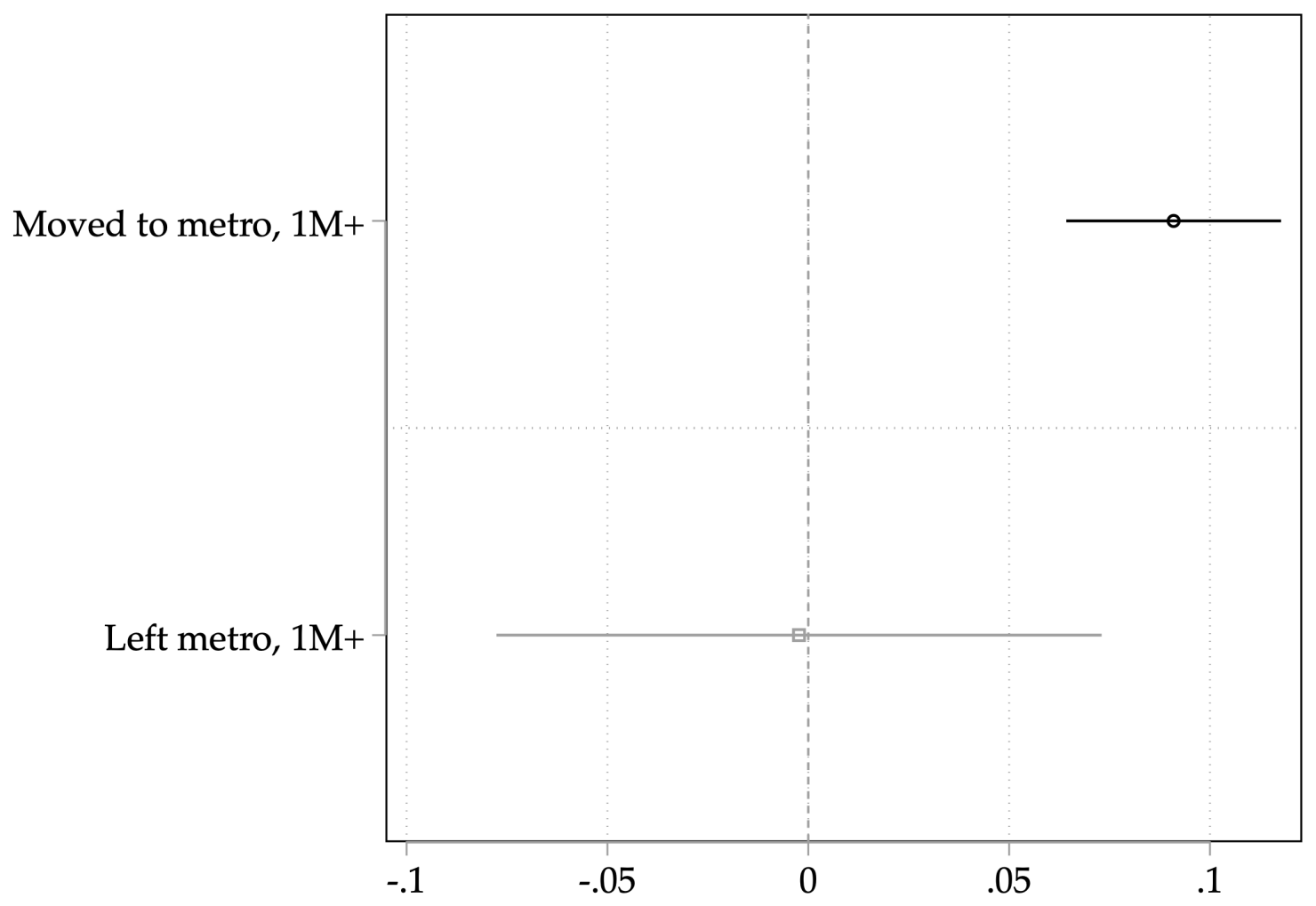

Notes: Points represent the predicted probability than an individual will oppose a proposed FMA based on their decision to move to or leave a metro area with a population greater than 1 million. The horizontal lines are 95 percent confidence intervals. Full estimates presented in section $\mathbf{F}$ of the SI file.

with a population of more than 1 million people is largely unrelated to an individuals opposition to a proposed FMA. Overall, then, the panel data indicate that moving to a large metro area of the US has a causal impact on support for LGBT rights. Therefore, we find strong support for $\mathbf{H} \mathbf{3 a}$

\subsection{Does Lifelong Exposure to Urban Environments Increase Support for LGBT Rights?}

To test whether lifelong exposure to urban environments increases support for LGBT rights $(\mathbf{H} 3 \mathbf{b})$, I examine how support for the right to marry varies by how long individu- 
als have lived in their current community. The 2016 CCES contains a continuous measure indicating how long a respondent has lived in their current area (0-100 years). To test H3a, I interact a measure of urban/rural area status with the continuous measure of community tenure. If time spent living in urban environments is associated with greater support for LGBT rights, then we should expect to support for the right to marry among those living in the largest metro areas of the US to increase as CCES respondents report living a greater length of time in their current communities.

Figure 5 depicts the predicted level of support for the right to marry across values of the community tenure measure for different geographic contexts. As indicated by the top left panel in Figure 5, a resident of a metro area with a population greater than 1 million people who has lived in their current community for less than one year has a .65 predicted probability of supporting the right to marry. By contrast, a resident of a metro area with a population greater than 1 million people who has lived in their current community for 90 years or more has a .75 predicted probability of supporting the right to marry. Therefore, increases in community tenure within the largest metro areas of the US are associated with a 10-point increase in the predicted probability that an individual will be supportive of the right to marry $(p<.001)$.

Among those living in other areas, increased time spent living in one's community is either unrelated to support for the right to marry or is associated with a decrease in support. The relationship between community tenure and support for the right to marry among residents in metro areas with population between 250k and 1 million people or metros with fewer than 250k people is curvilnear, meaning that differences in support between those who have just moved to their communities and those who have spent 90 years or more in their communities are not distinguishable from zero. For the remaining geographic categories, however, we observe a negative relationship between community tenure and support for the right to marry, meaning that increased time spent living in one's community is actually associated with lower support for the right to marry. These 
Figure 5: Support for Right to Marry Across Geographies, Conditioned by Length of Residence

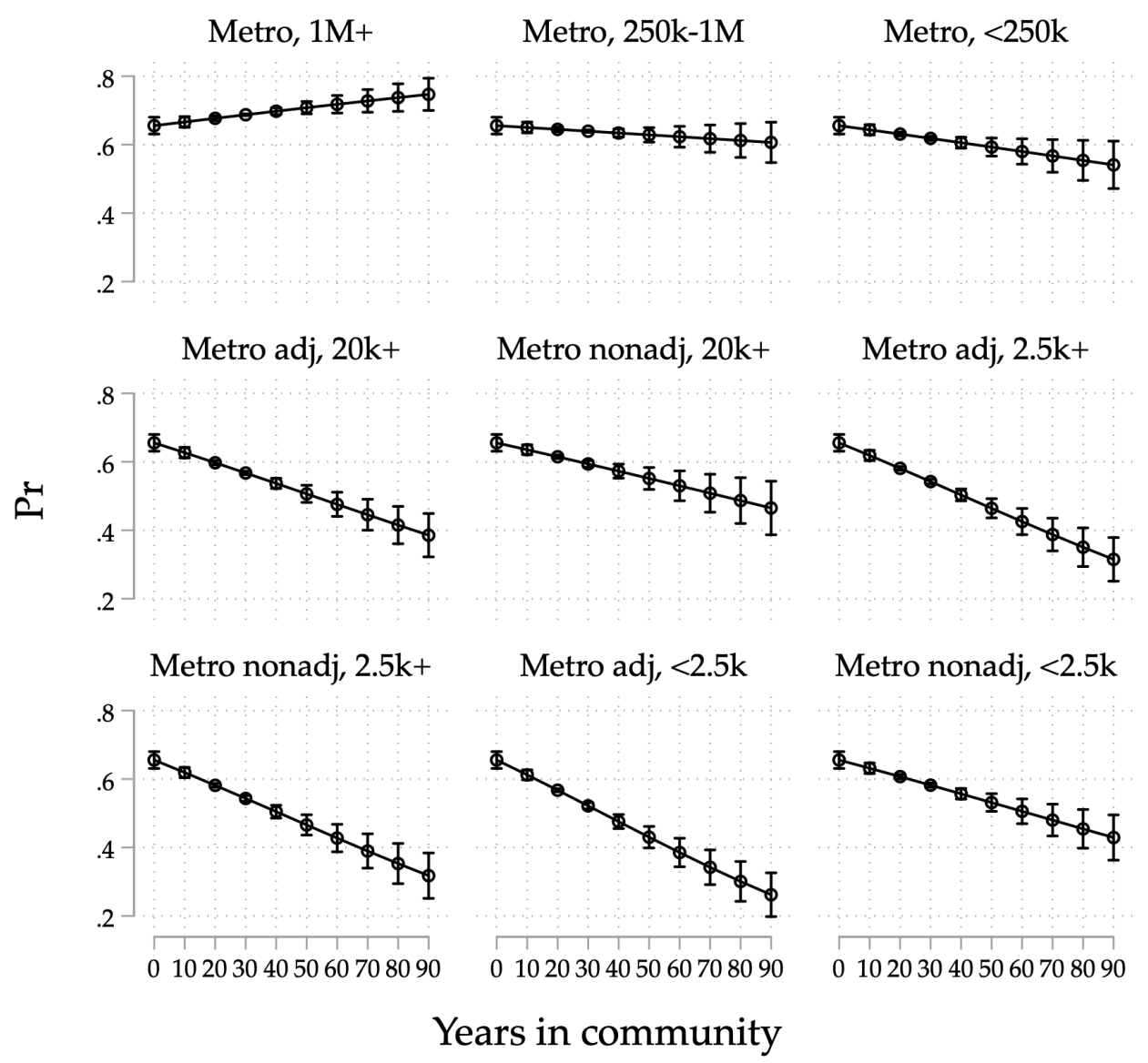

Notes: Points depict the predicted level of support for the right to marry across values of the measure for community tenure by different geographic contexts. The vertical lines are 95 percent confidence intervals. Predicted probabilities calculated by holding all other variables constant or at their respective mean values. Full estimates presented in section G of the SI file.

trends provide further evidence that it is lifelong residence within large cities in particular that is conducive of higher support for LGBT rights.

\subsection{Testing for Reverse Causality: Geographic Sorting}

Lastly, to test for the effects of geographic sorting (H4a-H4b), I estimate two models that regress moving to-and-from large metro areas of the US against an individuals support for/opposition to LGBT rights. Turning again to the 2010-2014 CCES Panel Study, I 
utilize a panel design that estimates whether an individual's opposition to/support for a proposed FMA shapes moving preferences within metro areas with more than 1 million people. In model 1, I regress an individuals choice to move to a metro area with more than 1 million people on a lagged measure of opposition to a proposed FMA. In model 2, I regress an individuals choice to leave a metro area with a population more than 1 million people on a lagged measure of support for a proposed FMA. Importantly, this design allow me to assess how homopositive and homonegative attitudes impact moving preferences over time.

Figure 6 graphs the predicted probability that an individual will move to or from a metro area with more than one million people between 2010 and 2014 based on their prior level of support for a proposed FMA. For homopositive or homonegative attitudes to have a causal effect on moving preferences, we should expect to observe predicted probabilities to the right of the x-axis in Figure 6 . I begin by examining the impact of homopositive attitudes on individuals' preferences for selecting into metro areas with more than one million people. As indicated by Figure 6, an individuals prior opposition to a proposed FMA is associated with a .005 -point increase in the probability that an individual will select into a metro area with more than 1 million residents. While this would seem to support the logic of $\mathbf{H 4 a}$, it is important to note that the lower bound of confidence interval overlaps with the reference line in Figure 6, indicating that the effects observed do not meet the .05 threshold for statistical significance. In a similar pattern of results, estimates for individuals who leave metro areas of the US with a population of more than 1 million people do not support the logic of geographic sorting. As further evidenced by Figure 6, postestimations from Model 2 indicate that an individuals prior support for a proposed FMA does not influence whether that same individual moved out of a metro area with more than 1 million residents. Given these insignificant results, we are able to successfully eliminate the possibility of reverse causality through geographic sorting. 
Figure 6: The Impact of Homopositive and Homonegative Attitudes on Moving Preferences

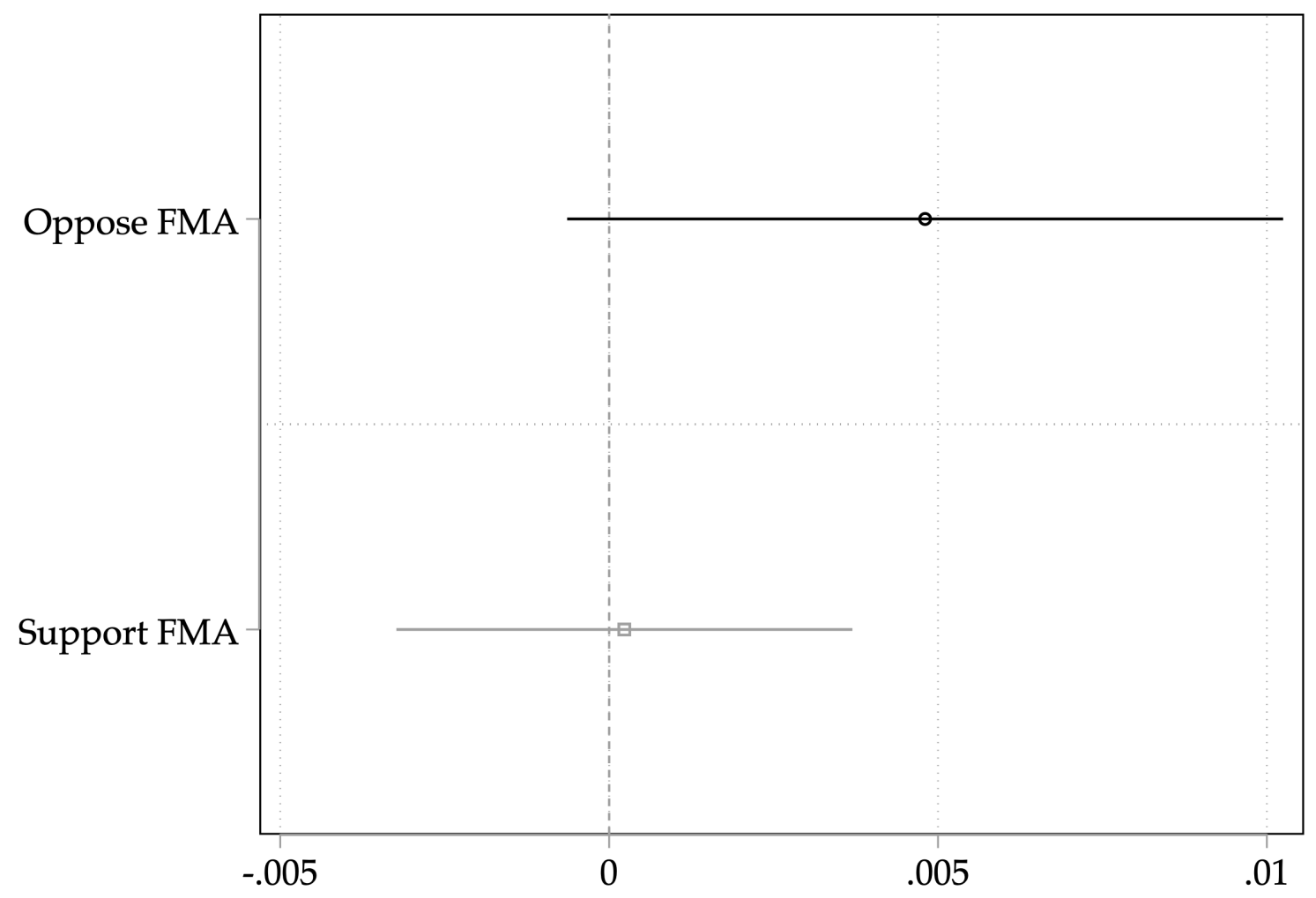

Notes: Points represent the predicted probability that an individual will move to or from a metro area with more than one million residents between 2010 and 2014 based on their prior level of opposition to/support for a proposed FMA. The horizontal lines are 95 percent confidence intervals. Full estimates presented in secction $\mathbf{H . 1}$ of the SI file.

\section{Discussion}

This paper provides a test of the relationship between urbanicity and support for LGBT rights with cross-sectional data from the GSS, PRRI, and CES/CCES surveys, as well as panel data from the 2010-2014 CCES Panel Study. Taken together, the results indicate that urban residence is conducive of greater support for LGBT rights. Support for LGBT rights is higher in urban contexts because of the greater opportunities for intergroup contact in such areas. Lifelong exposure to large metro areas of the US is associated with higher support for LGBT rights than exposure to a variety of other geographic contexts, and those who move to America's largest cities likewise exhibit increased support 
for LGBT rights over time. Moreover, it is not the case that homopositive or homonegative attitudes influence whether individuals choose to move to-or-from large metro areas of the US.

This paper makes three important contributions to the existing scholarship. First, the paper adds to the extant scholarship on the increasing geographic polarization of political attitudes. In particular, the results are consistent with an emerging scholarship that attests to there being a strong geographic component to support for rights for marginalized outgroups such as immigrants and other ethnic minorities (Maxwell 2019). By demonstrating that there is a geographic divide in public support for LGBT rights, the paper therefore extends the generalizability of extant models concerning the geographic polarization of attitudes towards outgroups to include sexual and gender minorities.

Second, the results underscore the importance of urbanicity as an explanatory variable in analyses of public opinion on LGBT rights. While studies demonstrate how a variety of socio-political and demographic factors shape support for LGBT rights (Castle 2019. Olson, Cadge \& Harrison 2006, Sherkat, Vries \& Creek 2010, Sherkat, Powell-Williams, Maddox \& Vries 2011), we have seen a noteworthy paucity on the importance of structural factors - and specifically geographic context - in engendering support for LGBT rights. By providing a comprehensive elucidation of how urbanicity imparts a significant influence on mass attitudes towards LGBT rights, my paper demonstrates why it is important for scholars to include some sort of control for urban residence in future studies of public opinion in the field of LGBT politics.

Lastly, the results contribute to extant debates about the importance of intergroup contact in engendering higher support for LGBT rights. Prior research establishes a robust relationship between positive intergroup contact at the individual/contextual level and higher support for LGBT rights (Barth, Overby \& Huffmon 2009, Earle, Hoffarth, Prusaczyk, MacInnis \& Hodson 2021, Garner 2013, Herek \& Capitanio 1996, MacInnis, Page-Gould \& Hodson|2017, Tadlock, Flores, Haider-Markel, Lewis, Miller \& Taylor 2017). 
However, an important omission in this body of scholarship is that such studies largely ignore the impact of the geographic clustering of LGBT individuals in large cities (Conron et al. 2020). The fact that 88.3 percent of LGBT-identifying individuals live in an urban area of the US (Badgett et al. 2019) suggests that the relationship between group contact and support for LGBT is likely to be highly conditional on urban residence. In this paper, I have I address this critical lacuna by providing an approximation of how support for LGBT rights varies within America's largest cities according to metro-level LGBT population density. In doing so, the paper adds to the debate on intergroup contact and support for LGBT rights by highlighting that such dynamics are contingent on specific geographic contexts.

\subsection{Limitations and Future Directions}

The current study is limited in that the panel survey used to test for within-subject changes in support for LGBT rights as individuals move to-and-from large metro areas of the US was fielded between 2010-2014. As such, the 2010-2014 CCES Panel Study does not contain measures gauging support for policies that define much of the contemporary debate on LGBT rights - for instance, opposition to bathroom bills and support for antidiscrimination laws. Where possible, future studies looking to test the causal effect of urban residence on support for LGBT rights should utilize longitudinal datasets containing items tapping public support for a broad range of LGBT-related policy measures. 


\section{Bibliography}

Agnew, C. R., Thompson, V. R., Smith, V. R., Gramzow, R. H. \& Currey, D. P. (1993), 'Proximal and distal predictors of homophobia: Framing the multivariate roots of outgroup rejection', Journal of Applied Social Psychology 23(24), 2013-2042.

Allport, G. W. (1954), The nature of prejudice, Addison-Wesley, Cambridge, MA.

Annes, A. \& Redlin, M. (2012), 'Coming out and coming back: rural gay migration and the city', Journal of Rural Studies 28, 56-68.

Atkins, C. J. (2021), 'Republicans prepare transphobic offensive for 2022 elections', People's World.

URL: $\quad$ https://www.peoplesworld.org/article/republicans-prepare-transphobia-offensive-for2022-elections/

Badgett, M. L., Choi, S. K. \& Wilson, B. D. (2019), LGBT poverty in the United States: A study of differences between sexual orientation and gender identity groups, The Williams Institue, UCLA, Los Angeles, CA.

Barth, J., Overby, M. \& Huffmon, S. H. (2009), ‘Community context, personal contact, and support for an anti-gay rights referendum', Political Research Quarterly 62(2), 355-365.

Baunach, D. M. (2012), 'Changing same-sex marriage attitudes in america from 1988 through 2010', Public Opinion Quarterly 76(2), 364-378.

Bishop, B. (2009), The big sort: Why the clustering of like-minded America is tearing us apart, Houghton Mifflin Harcourt, Boston, MA.

Cao, X. \& Gurcay, A. (2021), 'The anxiety factor: Moral traditionalism, interpersonal contact diversity and support for transgender candidates and rights', Journal of Homosexuality pp. 1-24. 
Castle, J. (2019), ‘New fronts in the culture wars? religion, partisanship, and polarization on religious liberty and transgender rights in the united states', American Politics Research 47(3), 650-679.

Cho, W. K. T., Gimpell, J. G. \& Hui, I. S. (2013), 'Voter migration and the geographic sorting of the american electorate', Annals of the Association of American Geographers 103(4), 856-870.

Conron, K. J., Luhur, W. \& Goldberg, S. K. (2020), Estimated Number of US LGBT Adults in Large Metropolitan Statistical Areas (MSAs), The Williams Institute, UCLA, Los Angeles, CA.

Curtis, J. (2021), 'The effect of the 2020 racial justice protests on attitudes and preferences in rural and urban america', Social Science Quarterly pp. 1-18.

Davies, K., Tropp, L. R., Aron, A., Pettigrew, T. F. \& Wright, S. C. (2011), ‘Cross-group friendships and intergroup attitudes: A meta-analytic review', Personality and Social Psychology Review 15(4), 332-351.

Dyck, J. J. \& Pearson-Merkowitz, S. (2014), 'To know you is not necessarily to love you: The partisan mediators of intergroup contact', Political Behavior 36(3), 553-580.

Earle, M., Hoffarth, M. R., Prusaczyk, E., MacInnis, C. \& Hodson, G. (2021), 'A multilevel analysis of lgbt (lesbian, gay, bisexual, transgender) rights support across 77 countries: The role of contact and country laws', British Journal of Social Psychology 60(3), 851-869.

Fiorina, M. P. \& Abrams, S. J. (2008), 'Political polarization in the american public', Annual Review of Political Science 11, 563-588.

Flores, A. R. (2015), 'Attitudes toward transgender rights: perceived knowledge and secondary interpersonal contact', Politics, Groups, and Identities 3(3), 398-416. 
Flores, A. R., Haider-Markel, D. P., Lewis, D. C., Miller, P. R., Tadlock, B. L. \& Taylor, J. K. (2018), 'Transgender prejudice reduction and opinions on transgender rights: Results from a mediation analysis on experimental data', Research and Politics 5(1), 1-7.

Flores, A. R., Mallory, C. \& Conron, K. J. (2020), 'Public attitudes about emergent issues in lgbtq rights: Conversion therapy and religious refusals', Research and Politics 7(4), 1-9.

Garner, A. (2013), 'Ambivalence, the intergroup contact hypothesis, and attitudes about gay rights', Politics and Policy 41(2), 241-266.

Ghaziani, A. (2015), There goes the gayborhood?, Princeton University Press, Princeton, NJ.

Gimpel, J. G., Lovin, N., Moy, B. \& Reeves, A. (2020), 'The urban-rural gulf in american political behavior', Political Behavior 42, 1343-1368.

Herek, G. M. \& Capitanio, J. P. (1996), '"some of my best friends' intergroup contact, concealable stigma, and heterosexuals' attitudes toward gay men and lesbians', Personality and Social Psychology Bulletin 22(4), 412-424.

Jones, P. E., Brewer, P. R., Young, D. G., Lambe, J. L. \& Hoffman, L. H. (2018), 'Explaining public opinion toward transgender people, rights, and candidates', Public Opinion Quarterly 82(2), 252-278.

Kelly, P. \& Lobao, L. (2019), 'The social bases of rural-urban political divides: Social status, work, and sociocultural beliefs', Rural Sociology 84(4), 669-705.

Lang, C. \& Pearson-Merkowitz, S. (2015), 'Partisan sorting in the united states, 1972-2012: New evidence from a dynamic analysis', Political Geography 48, 119-129.

Lewis, D. C., Flores, A. R., Haider-Markel, D. P., Miller, P. R. \& Taylor, J. K. (2017), ‘Degrees of acceptance: Variation in public attitudes toward segments of the lgbt community', Political Research Quarterly 70(4), 861-875. 
Lewis, D. C., Tadlock, B. L., Flores, A. R., Haider-Markel, D. P., Miller, P. R. \& Taylor, J. K. (2021), 'Public attitudes on transgender military service: The role of gender', Armed Forces Society 47(2), 276-297.

lunz Trujillo, K. (2022), 'Rural identity as a contributing factor to anti-intellectualism in the u.s.', Political Behavior pp. 1-24.

MacInnis, C., Page-Gould, E. \& Hodson, G. (2017), 'Multilevel intergroup contact and antigay prejudice (explicit and implicit): Evidence of contextual contact benefits in a less visible group domain', Social Psychological and Personality Science 8(3), 243-251.

Martin, G. J. \& Webster, S. W. (2020), ‘Does residential sorting explain geographic polarization?', Political Science Research and Methods 8(2), 215-231.

Maxwell, R. (2019), ‘Cosmopolitan immigration attitudes in large european cities: Contextual or compositional effects?', American Political Science Review 113(2), 456-474.

Mummolo, J. \& Nall, C. (2017), ‘Why partisans do not sort: The constraints on political segregation', Journal of Politics 79(1), 45-59.

Munis, B. K. (2021), 'Place, candidate roots, and voter preferences in an age of partisan polarization: Observational and experimental evidence', Political Geography 85, 1-12.

Nemerever, Z. \& Rogers, M. (2021), 'Measuring the rural continuum in political science', Political Analysis 29(3), 267-286.

Olson, L. R., Cadge, W. \& Harrison, J. T. (2006), 'Religion and public opinion about samesex marriage', Social Science Quarterly 87(2), 340-360.

Poteat, V. P. (2007), ‘Peer group socialization of homophobic attitudes and behavior during adolescence', Peer Group Socialization of Homophobic Attitudes and Behavior During Adolescence 78(6), 1830-1842. 
Powers, S. L., Graefe, A. R., Benfield, J. A., Hickerson, B., Baker, B. L., Mullenbach, L. E. \& Mowen, A. J. (2021), 'Exploring the conditions that promote intergroup contact at urban parks', Journal of Leisure Research pp. 1-24.

Rosenberg, R. (2016), 'The whiteness of gay urban belonging: Criminalizing lgbtq youth of color in queer spaces of care', Urban Geography 38(1), 137-148.

Scala, D. J. \& Johnson, K. M. (2017), 'Political polarization along the rural-urban continuum? the geography of the presidential vote, 2000-2016', The ANNALS of the American Academy of Political and Social Science 672(1), 162-184.

Sherkat, D. E., Powell-Williams, M., Maddox, G. \& Vries, K. M. D. (2011), 'Religion, politics, and support for same-sex marriage in the united states, 1988-2008', Social Science Research 40(1), 167-180.

Sherkat, D. E., Vries, K. M. D. \& Creek, S. (2010), ‘Race, religion, and opposition to samesex marriage', Social Science Quarterly 91(1), 80-98.

Smith, D. A., DeSantis, M. \& Kassel, J. (2006), 'Same-sex marriage ballot measures and the 2004 presidential election', State and Local Government Review 38(2), 78-91.

Stewart-Winter, T. (2015), Queer Clout: Chicago and the Rise of Gay Politics, Pennsylvania University Press, Philadelphia, PA.

Tadlock, B. L., Flores, A. R., Haider-Markel, D. P., Lewis, D. C., Miller, P. R. \& Taylor, J. K. (2017), 'Testing contact theory and attitudes on transgender rights', Public Opinion Quarterly 81(4), 956-976.

Valentine, G. (2008), 'Living with difference: reflections on geographies of encounter', Progress in Human Geography 32(3), 323-337.

Weston, K. (1995), 'Get thee to a big city: Sexual imaginary and the great gay migration', GLQ: A Journal of Gay and Lesbian Studies 2(3), 253-277. 
Wilson, H. F. (2011), 'Passing propinquities in the multicultural city: The everyday encounters of bus passengering', Environment and Planning 43(3), 634-649.

Wilson, H. F. (2013), 'Collective life: parents, playground encounters and the multicultural city', Social Cultural Geography 14(6), 625-648.

Wilson, H. F. (2017), 'On geography and encounter: Bodies, borders, and difference', Progress in Human Geography 41(4), 451-471. 
Supplemental Information

\begin{tabular}{|l|l|l|l|l|l|}
\hline A Distribution of Respondents Across Urban-Rural Classification Schema & 2
\end{tabular}

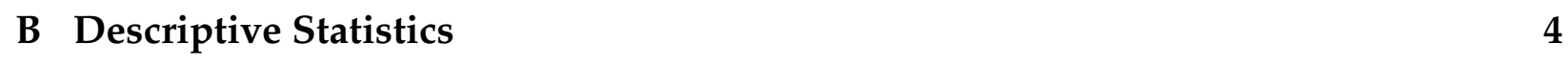

B.1 Full Samples . . . . . . . . . . . . . . . . . . . . . . . 4

B.2 By Area-Level Geography $\ldots \ldots \ldots \ldots \ldots \ldots$

\begin{tabular}{|l|l|}
\hline C Geographic Context and Support for LGBT Rights & 12
\end{tabular}

C.1 Pooled GSS . . . . . . . . . . . . . . . . . . . . . . . . . . . . . . . . 12

C.2 Replication with 2019 PRRI $\ldots \ldots \ldots \ldots$. . . . . . . . . . 13

\begin{tabular}{|l|l|}
\hline D Testing for Compositional Effects & 14
\end{tabular}

E LGBT Population Density in Large Metro Areas and Opposition to Transgen-

$\begin{array}{ll}\text { der Military Ban } & 15\end{array}$

F The Impact of Moving Preferences on Opposition to Federal Marriage Amend$\begin{array}{ll}\text { ment } & 16\end{array}$

\begin{tabular}{|lll}
\hline G Exposure to Urban Environments and Support for the Right to Marty & 17
\end{tabular}

H The Impact of Opposition to/Support for Federal Marriage Amendment on

\begin{tabular}{ll} 
Moving Preferences & 18 \\
\hline
\end{tabular}




\section{A Distribution of Respondents Across Urban-Rural Clas- sification Schema}

Table 1: Pooled GSS

\begin{tabular}{lc}
\hline & $\%$ \\
\hline 12 largest SMSAs & $8.65 \%$ \\
SMSAs, 13-100 largest & $12.61 \%$ \\
Suburb, 12 largest & $13.81 \%$ \\
Suburb, 13-100 & $16.73 \%$ \\
Other urban & $36.98 \%$ \\
Other rural & $11.18 \%$ \\
\hline
\end{tabular}

Notes: Weighted estimates.

Table 2: 2019 PRRI

\begin{tabular}{lc}
\hline & $\%$ \\
\hline Metro $\quad 80.41 \%$ \\
Nonmetro $\quad 19.58 \%$ \\
\hline Notes: Weighted esti- \\
mates.
\end{tabular}

Table 3: 2020 CCES

\begin{tabular}{ll}
\hline & $\%$ \\
\hline Metro, 1M+ & $52.76 \%$ \\
Metro, 250k-1M & $22.60 \%$ \\
Metro, <250k & $9.69 \%$ \\
Metro adj, 20k+ & $4.80 \%$ \\
Metro nonadj, 20k+ & $1.55 \%$ \\
Metro adj, 2.5k+ & $4.62 \%$ \\
Metro nonadj, 2.5k+ & $2.53 \%$ \\
Metro adj, $<2.5 \mathrm{k}$ & $.68 \%$ \\
Metro nonadj, <2.5k & $.73 \%$ \\
\hline \multicolumn{2}{l}{ Notes: Weighted estimates. }
\end{tabular}


Table 4: 2010-2014 CCES Panel

\begin{tabular}{lll}
\hline & 2010 & 2014 \\
\hline Metro, 1M+ & $51.62 \%$ & $51.80 \%$ \\
Metro, 250k-1M & $22.01 \%$ & $22.32 \%$ \\
Metro, $<250 \mathrm{k}$ & $11.21 \%$ & $11.06 \%$ \\
Metro adj, 20k+ & $5.08 \%$ & $4.77 \%$ \\
Metro nonadj, 20k+ & $1.31 \%$ & $1.26 \%$ \\
Metro adj, 2.5k+ & $4.60 \%$ & $4.53 \%$ \\
Metro nonadj, 2.5k+ & $2.79 \%$ & $2.88 \%$ \\
Metro adj, $<2.5 \mathrm{k}$ & $.71 \%$ & $.72 \%$ \\
Metro nonadj, $<2.5 \mathrm{k}$ & $.63 \%$ & $.62 \%$ \\
\hline
\end{tabular}

Notes: Weighted estimates.

Table 5: 2016 CCES

\begin{tabular}{lc}
\hline & $\%$ \\
\hline Metro, 1M+ & $54.27 \%$ \\
Metro, 250k-1M & $21.83 \%$ \\
Metro, $<250 \mathrm{k}$ & $9.66 \%$ \\
Metro adj, 20k+ & $4.72 \%$ \\
Metro nonadj, 20k+ & $1.43 \%$ \\
Metro adj, 2.5k+ & $4.36 \%$ \\
Metro nonadj, 2.5k+ & $2.42 \%$ \\
Metro adj, $<2.5 \mathrm{k}$ & $.60 \%$ \\
Metro nonadj, <2.5k & $.67 \%$ \\
\hline \multicolumn{2}{l}{ Notes: Weighted estimates. }
\end{tabular}

Notes: Weighted estimates. 


\section{B Descriptive Statistics}

Table 6: Pooled GSS

\begin{tabular}{lcccc}
\hline & Mean & SD & Min & Max \\
\hline Ideology (Liberal) & 3.896 & .013 & 1 & 7 \\
White, non-Hispanic & $70.92 \%$ & .004 & 0 & 1 \\
Black, non-Hispanic & $12.41 \%$ & .003 & 0 & 1 \\
Hispanic & $12.27 \%$ & .003 & 0 & 1 \\
Other race, non-Hispanic & $4.38 \%$ & .002 & 0 & 1 \\
Age & 43 years & .150 & 18 & 89 \\
Female & $51.7 \%$ & .004 & 0 & 1 \\
LGB & $3.75 \%$ & .001 & 0 & 1 \\
Education & 2.678 & .011 & 1 & 5 \\
Nonreligious & $19.16 \%$ & .003 & 0 & 1 \\
\hline
\end{tabular}

Notes: Weighted estimates.

\section{B.1 Full Samples}

Table 7: 2019 PRRI

\begin{tabular}{lcccc}
\hline & Mean & SD & Min & Max \\
\hline Ideology (Liberal) & 2.903 & .044 & 1 & 5 \\
White, non-Hispanic & $63.20 \%$ & .018 & 0 & 1 \\
Black, non-Hispanic & $12.45 \%$ & .013 & 0 & 1 \\
Hispanic & $16.49 \%$ & .014 & 0 & 1 \\
Other race, non-Hispanic & $7.8 \%$ & .011 & 0 & 1 \\
Age & 47.64 years & .662 & 18 & 97 \\
Female & $52.55 \%$ & .018 & 0 & 1 \\
LGBT & $7.8 \%$ & .010 & 0 & 1 \\
Education & 2.967 & .045 & 1 & 5 \\
Nonreligious & $21.17 \%$ & .015 & 0 & 1 \\
\hline
\end{tabular}

Notes: Weighted estimates. 
Table 8: 2020 CES

\begin{tabular}{lcccc}
\hline & Mean & SD & Min & Max \\
\hline Ideology (Liberal) & 4.275 & .010 & 1 & 7 \\
White, non-Hispanic & $66.53 \%$ & .002 & 0 & 1 \\
Black, non-Hispanic & $13.59 \%$ & .001 & 0 & 1 \\
Hispanic & $10.64 \%$ & .001 & 0 & 1 \\
Other race, non-Hispanic & .092 & .001 & 0 & 1 \\
Age & 47.90 years & .097 & 18 & 95 \\
Female & $55.99 \%$ & .002 & 0 & 1 \\
Cis/straight & $82.78 \%$ & .002 & 0 & 1 \\
LGBT & $13.43 \%$ & .001 & 0 & 1 \\
Nondisclosed & $3.77 \%$ & .001 & 0 & 1 \\
Education & 3.808 & .008 & 1 & 6 \\
Nonreligious & $36.84 \%$ & .002 & 0 & 1 \\
\hline
\end{tabular}

Notes: Weighted estimates.

Table 9: 2016 CCES

\begin{tabular}{lcccc}
\hline & Mean & SD & Min & Max \\
\hline Ideology (Liberal) & 3.745 & .010 & 1 & 7 \\
White, non-Hispanic & $74.92 \%$ & .003 & 0 & 1 \\
Black, non-Hispanic & $10.59 \%$ & .002 & 0 & 1 \\
Hispanic & $6.72 \%$ & .002 & 0 & 1 \\
Other race, non-Hispanic & $7.75 \%$ & .001 & 0 & 1 \\
Age & 49.09 years & .122 & 18 & 99 \\
Female & $53.08 \%$ & .003 & 0 & 1 \\
Cis/straight & $87.96 \%$ & .002 & 0 & 1 \\
LGBT & $9.90 \%$ & .001 & 0 & 1 \\
Nondisclosed & $3.11 \%$ & .001 & 0 & 1 \\
Education & 3.294 & .010 & 1 & 6 \\
Nonreligious & $29.26 \%$ & .002 & 0 & 1 \\
Years in community & 16.92 years & .102 & 0 & 100 \\
\hline
\end{tabular}

Notes: Weighted estimates. 
Table 10: 2010-2014 CCES Panel

\begin{tabular}{lcccccccc}
\hline & \multicolumn{3}{c}{2010} & & \multicolumn{5}{c}{2014} \\
\hline Ideology (Liberal) & Mean & SD & Min & Max & Mean & SD & Min & Max \\
White, non-Hispanic & 2.578 & .024 & 1 & 5 & 2.797 & .021 & 1 & 5 \\
Black, non-Hispanic & $74.77 \%$ & .011 & 0 & 1 & $74.40 \%$ & .011 & 0 & 1 \\
Hispanic & $11.81 \%$ & .008 & 0 & 1 & $12.03 \%$ & .008 & 0 & 1 \\
Other race, non-Hispanic & $6.77 \%$ & .006 & 0 & 1 & $7.30 \%$ & .007 & 0 & 1 \\
Age & $6.63 \%$ & .006 & 0 & 1 & $6.26 \%$ & .006 & 0 & 1 \\
Female & 48.125 years & .424 & 18 & 91 & 52.102 years & .425 & 22 & 95 \\
Education & $52.03 \%$ & .011 & 0 & 1 & $52.03 \%$ & .011 & 0 & 1 \\
Nonreligious & 3.340 & .030 & 1 & 6 & 3.426 & .034 & 1 & 6 \\
\hline
\end{tabular}

Notes: Weighted estimates. 


\section{B.2 By Area-Level Geography}

Table 11: Metro, 1M+

\begin{tabular}{lcccc}
\hline & Mean & SD & Min & Max \\
\hline Ideology (Liberal) & 4.097 & .013 & 1 & 7 \\
White, non-Hispanic & $61.37 \%$ & .004 & 0 & 1 \\
Black, non-Hispanic & 15.74 years & .003 & 0 & 1 \\
Hispanic & $12.71 \%$ & .003 & 0 & 1 \\
Other race, non-Hispanic & $10.15 \%$ & .002 & 0 & 1 \\
Age & 47.57 years & .152 & 18 & 95 \\
Female & $50.91 \%$ & .004 & 0 & 1 \\
Cis/straight & $82.34 \%$ & .003 & 0 & 1 \\
LGBT & $12.72 \%$ & .002 & 0 & 1 \\
Nondisclosed & $4.92 \%$ & .002 & 0 & 1 \\
Education & 3.533 & .014 & 1 & 6 \\
Nonreligious & $34.18 \%$ & .003 & 0 & 1 \\
\hline
\end{tabular}

Notes: Weighted estimates.

Table 12: Metro, 250K-1M

\begin{tabular}{lcccc}
\hline & Mean & SD & Min & Max \\
\hline Ideology (Liberal) & 3.808 & .022 & 1 & 7 \\
White, non-Hispanic & $71.47 \%$ & .006 & 0 & 1 \\
Black, non-Hispanic & $10.88 \%$ & .004 & 0 & 1 \\
Hispanic & $9.82 \%$ & .004 & 0 & 1 \\
Other race, non-Hispanic & $7.81 \%$ & .004 & 0 & 1 \\
Age & 48.65 years & .243 & 18 & 95 \\
Female & $51.72 \%$ & .006 & 0 & 1 \\
Cis/straight & $84.40 \%$ & .005 & 0 & 1 \\
LGBT & $11.23 \%$ & .003 & 0 & 1 \\
Nondisclosed & $4.35 \%$ & .003 & 0 & 1 \\
Education & 3.311 & .020 & 1 & 6 \\
Nonreligious & $35.28 \%$ & .006 & 0 & 1 \\
\hline
\end{tabular}

Notes: Weighted estimates. 
Table 13: Metro, <250k

\begin{tabular}{lcccc}
\hline & Mean & SD & Min & Max \\
\hline Ideology (Liberal) & 3.637 & .034 & 1 & 7 \\
White, non-Hispanic & $80.23 \%$ & .008 & 0 & 1 \\
Black, non-Hispanic & $9.31 \%$ & .006 & 0 & 1 \\
Hispanic & $4.71 \%$ & .004 & 0 & 1 \\
Other race, non-Hispanic & $5.73 \%$ & .005 & 0 & 1 \\
Age & 48.766 years & .385 & 18 & 95 \\
Female & $50.55 \%$ & .009 & 0 & 1 \\
Cis/straight & $86.51 \%$ & .006 & 0 & 1 \\
LGBT & $9.82 \%$ & .005 & 0 & 1 \\
Nondisclosed & $3.56 \%$ & .003 & 0 & 1 \\
Education & 3.229 & .028 & 1 & 6 \\
Nonreligious & $34.41 \%$ & .009 & 0 & 1 \\
\hline
\end{tabular}

Notes: Weighted estimates.

Table 14: Metro adj, 20k+

\begin{tabular}{lcccc}
\hline & Mean & SD & Min & Max \\
\hline Ideology (Liberal) & 3.158 & .046 & 1 & 7 \\
White, non-Hispanic & $83.68 \%$ & .012 & 0 & 1 \\
Black, non-Hispanic & $7.92 \%$ & .009 & 0 & 1 \\
Hispanic & $3.35 \%$ & .006 & 0 & 1 \\
Other race, non-Hispanic & $5.03 \%$ & .008 & 0 & 1 \\
Age & 49.37 years & .503 & 18 & 95 \\
Female & $54.29 \%$ & .013 & 0 & 1 \\
Cis/straight & $85.54 \%$ & .011 & 0 & 1 \\
LGBT & $9.86 \%$ & .007 & 0 & 1 \\
Nondisclosed & $4.5 \%$ & .009 & 0 & 1 \\
Education & 3.070 & .036 & 1 & 6 \\
Nonreligious & $32.34 \%$ & .012 & 0 & 1 \\
\hline
\end{tabular}

Notes: Weighted estimates. 
Table 15: Metro nonadj, 20k+

\begin{tabular}{lcccc}
\hline & Mean & SD & Min & Max \\
\hline Ideology (Liberal) & 3.598 & .076 & 1 & 7 \\
White, non-Hispanic & $79.27 \%$ & .023 & 0 & 1 \\
Black, non-Hispanic & $7.60 \%$ & .014 & 0 & 1 \\
Hispanic & $4.17 \%$ & .013 & 0 & 1 \\
Other race, non-Hispanic & $8.94 \%$ & .016 & 0 & 1 \\
Age & 49.03 years & .986 & 18 & 95 \\
Female & $52.83 \%$ & .024 & 0 & 1 \\
Cis/straight & $87.44 \%$ & .014 & 0 & 1 \\
LGBT & $8.23 \%$ & .010 & 0 & 1 \\
Nondisclosed & $4.32 \%$ & .010 & 0 & 1 \\
Education & 3.718 & .064 & 1 & 6 \\
Nonreligious & $35.94 \%$ & .023 & 0 & 1 \\
\hline
\end{tabular}

Notes: Weighted estimates.

Table 16: Metro adj, $2.5 \mathrm{k}+$

\begin{tabular}{lcccc}
\hline & Mean & SD & Min & Max \\
\hline Ideology (Liberal) & 3.326 & .044 & 1 & 7 \\
White, non-Hispanic & $83.32 \%$ & .010 & 0 & 1 \\
Black, non-Hispanic & $9.05 \%$ & .008 & 0 & 1 \\
Hispanic & $2.78 \%$ & .005 & 0 & 1 \\
Other race, non-Hispanic & $4.83 \%$ & .006 & 0 & 1 \\
Age & 50.28 years & .539 & 18 & 95 \\
Female & $54.37 \%$ & .013 & 0 & 1 \\
Cis/straight & $87.52 \%$ & .009 & 0 & 1 \\
LGBT & $9.15 \%$ & .007 & 0 & 1 \\
Nondisclosed & $3.32 \%$ & .006 & 0 & 1 \\
Education & 2.974 & .041 & 1 & 6 \\
Nonreligious & $31.22 \%$ & .013 & 0 & 1 \\
\hline
\end{tabular}

Notes: Weighted estimates. 
Table 17: Metro nonadj, $2.5 \mathrm{k}+$

\begin{tabular}{lcccc}
\hline & Mean & SD & Min & Max \\
\hline Ideology (Liberal) & 3.328 & .059 & 1 & 7 \\
White, non-Hispanic & $85.51 \%$ & .015 & 0 & 1 \\
Black, non-Hispanic & $6.09 \%$ & .011 & 0 & 1 \\
Hispanic & $2.66 \%$ & .005 & 0 & 1 \\
Other race, non-Hispanic & $5.72 \%$ & .011 & 0 & 1 \\
Age & 49.50 years & .654 & 18 & 95 \\
Female & $53.90 \%$ & .018 & 0 & 1 \\
Cis/straight & $87.52 \%$ & .013 & 0 & 1 \\
LGBT & $8.95 \%$ & .010 & 0 & 1 \\
Nondisclosed & $3.49 \%$ & .008 & 0 & 1 \\
Education & 3.044 & .056 & 1 & 6 \\
Nonreligious & $28.15 \%$ & .016 & 0 & 1 \\
\hline
\end{tabular}

Notes: Weighted estimates.

Table 18: Metro adj, $<2.5 \mathrm{k}$

\begin{tabular}{lcccc}
\hline & Mean & SD & Min & Max \\
\hline Ideology (Liberal) & 3.318 & .132 & 1 & 7 \\
White, non-Hispanic & $81.43 \%$ & .039 & 0 & 1 \\
Black, non-Hispanic & $9.01 \%$ & .029 & 0 & 1 \\
Hispanic & $4.15 \%$ & .025 & 0 & 1 \\
Other race, non-Hispanic & $5.39 \%$ & .021 & 0 & 1 \\
Age & 51.29 years & 1.558 & 18 & 95 \\
Female & $52.78 \%$ & .039 & 0 & 1 \\
Cis/straight & $81.92 \%$ & .039 & 0 & 1 \\
LGBT & $12.18 \%$ & .032 & 0 & 1 \\
Nondisclosed & $5.88 \%$ & .027 & 0 & 1 \\
Education & 2.740 & .108 & 1 & 6 \\
Nonreligious & $33.58 \%$ & .042 & 0 & 1 \\
\hline
\end{tabular}

Notes: Weighted estimates. 
Table 19: Metro nonadj, $<2.5 \mathrm{k}$

\begin{tabular}{lcccc}
\hline & Mean & SD & Min & Max \\
\hline Ideology (Liberal) & 3.371 & .108 & 1 & 7 \\
White, non-Hispanic & $87.57 \%$ & .028 & 0 & 1 \\
Black, non-Hispanic & $3.61 \%$ & .011 & 0 & 1 \\
Hispanic & $1.59 \%$ & .005 & 0 & 1 \\
Other race, non-Hispanic & $7.21 \%$ & .027 & 0 & 1 \\
Age & 52.436 years & 1.576 & 18 & 95 \\
Female & $57.28 \%$ & .036 & 0 & 1 \\
Cis/straight & $88.38 \%$ & .026 & 0 & 1 \\
LGBT & $8.87 \%$ & .025 & 0 & 1 \\
Nondisclosed & $2.73 \%$ & .008 & 0 & 1 \\
Education & 2.891 & .113 & 1 & 6 \\
Nonreligious & $31.54 \%$ & .035 & 0 & 1 \\
\hline
\end{tabular}

Notes: Weighted estimates. 


\section{Geographic Context and Support for LGBT Rights}

\section{C.1 Pooled GSS}

Table 20: Pooled GSS

\begin{tabular}{|c|c|c|c|c|c|}
\hline & $\begin{array}{l}\text { Right to } \\
\text { marry }\end{array}$ & $\begin{array}{c}\text { Same sex } \\
\text { relations }\end{array}$ & $\begin{array}{c}\text { Allow } \\
\text { homosexual } \\
\text { to speak }\end{array}$ & $\begin{array}{c}\text { Allow } \\
\text { homosexual } \\
\text { book }\end{array}$ & $\begin{array}{c}\text { Allow } \\
\text { homosexual } \\
\text { to teach }\end{array}$ \\
\hline Ideology (Liberal) & $\begin{array}{c}.209^{* * *} \\
(.005)\end{array}$ & $\begin{array}{c}-.169^{* * *} \\
(.010)\end{array}$ & $\begin{array}{c}-.106^{* * *} \\
(.019)\end{array}$ & $\begin{array}{c}-.097^{* * *} \\
(.013)\end{array}$ & $\begin{array}{c}-.110^{* * *} \\
(.016)\end{array}$ \\
\hline Black, non-Hispanic & $\begin{array}{c}-.280^{* * *} \\
(.059)\end{array}$ & $\begin{array}{c}-.414^{* * *} \\
(.069)\end{array}$ & $\begin{array}{c}-.334^{* * *} \\
(.071)\end{array}$ & $\begin{array}{c}-.349^{* * *} \\
(.047)\end{array}$ & $\begin{array}{c}-.268^{* * *} \\
(.032)\end{array}$ \\
\hline Hispanic & $\begin{array}{c}-.167^{* *} \\
(.056)\end{array}$ & $\begin{array}{c}-.186^{* * *} \\
(.052)\end{array}$ & $\begin{array}{l}-.211^{*} \\
(.083)\end{array}$ & $\begin{array}{c}-.239^{* *} \\
(.081)\end{array}$ & $\begin{array}{l}-.114^{*} \\
(.048)\end{array}$ \\
\hline Other race, non-Hispanic & $\begin{array}{l}-.088 \\
(.047)\end{array}$ & $\begin{array}{c}-.188^{* * *} \\
(.039)\end{array}$ & $\begin{array}{c}-.527^{* * *} \\
(.101)\end{array}$ & $\begin{array}{l}-.219 \\
(.141)\end{array}$ & $\begin{array}{c}-.389^{* *} \\
(.137)\end{array}$ \\
\hline Age & $\begin{array}{c}-.009^{* * *} \\
(.001)\end{array}$ & $\begin{array}{c}-.009^{* * *} \\
(.001)\end{array}$ & $\begin{array}{c}-.006^{* *} \\
(.002)\end{array}$ & $\begin{array}{c}-.011^{* * *} \\
(.002)\end{array}$ & $\begin{array}{c}-.011^{* * *} \\
(.032)\end{array}$ \\
\hline Female & $\begin{array}{c}.139^{* * *} \\
(.036)\end{array}$ & $\begin{array}{l}.198^{* * *} \\
(.029)\end{array}$ & $\begin{array}{c}.059 \\
(.040)\end{array}$ & $\begin{array}{c}.070 \\
(.036)\end{array}$ & $\begin{array}{l}.237^{* * *} \\
(.060)\end{array}$ \\
\hline LGB & $\begin{array}{l}.282^{* * *} \\
(.079)\end{array}$ & $\begin{array}{l}.362^{* * *} \\
(.062)\end{array}$ & $\begin{array}{c}.083 \\
(.100)\end{array}$ & $\begin{array}{l}.054 \\
(.212)\end{array}$ & $\begin{array}{c}.002 \\
(.182)\end{array}$ \\
\hline Education & $\begin{array}{l}.077^{* *} \\
(.019)\end{array}$ & $\begin{array}{l}.116^{* * *} \\
(.021)\end{array}$ & $\begin{array}{l}.319^{* * *} \\
(.022)\end{array}$ & $\begin{array}{l}.247^{* * *} \\
(.032)\end{array}$ & $\begin{array}{l}.318^{* * *} \\
(.025)\end{array}$ \\
\hline Nonreligious & $\begin{array}{l}.237^{* * *} \\
(.014)\end{array}$ & $\begin{array}{l}.342^{* * *} \\
(.028)\end{array}$ & $\begin{array}{l}.321^{* * *} \\
(.076)\end{array}$ & $\begin{array}{l}.253^{* * * *} \\
(.034)\end{array}$ & $\begin{array}{l}.257^{* * *} \\
(.061)\end{array}$ \\
\hline smsa's 13-100 & $\begin{array}{c}-.087^{* * * *} \\
(.021)\end{array}$ & $\begin{array}{l}-.041 \\
(.023)\end{array}$ & $\begin{array}{l}.178^{* * *} \\
(.025)\end{array}$ & $\begin{array}{c}.018 \\
(.032)\end{array}$ & $\begin{array}{c}-.085^{* * *} \\
(.021)\end{array}$ \\
\hline Suburb, 12 largest & $\begin{array}{l}-.028^{*} \\
(.012)\end{array}$ & $\begin{array}{l}.054^{* *} \\
(.019)\end{array}$ & $\begin{array}{l}.111^{* * *} \\
(.020)\end{array}$ & $\begin{array}{l}.114^{* * *} \\
(.019)\end{array}$ & $\begin{array}{c}-.121^{* * *} \\
(.009)\end{array}$ \\
\hline Suburb, $13-100$ & $\begin{array}{l}-.018 \\
(.022)\end{array}$ & $\begin{array}{c}.025 \\
(.033)\end{array}$ & $\begin{array}{l}.091^{*} \\
(.038)\end{array}$ & $\begin{array}{l}.138^{* * *} \\
(.031)\end{array}$ & $\begin{array}{c}-.073^{* *} \\
(.023)\end{array}$ \\
\hline Other urban & $\begin{array}{c}-.105^{* * *} \\
(.022)\end{array}$ & $\begin{array}{l}-.118^{* *} \\
(.034)\end{array}$ & $\begin{array}{l}-.049 \\
(.045)\end{array}$ & $\begin{array}{l}-.021 \\
(.043)\end{array}$ & $\begin{array}{c}-.179 * * * \\
(.026)\end{array}$ \\
\hline Rural & $\begin{array}{c}-.189^{* * * *} \\
(.031)\end{array}$ & $\begin{array}{l}-.244^{* *} \\
(.042)\end{array}$ & $\begin{array}{c}-.302^{* * *} \\
(.057)\end{array}$ & $\begin{array}{c}-.251^{* * *} \\
(.061)\end{array}$ & $\begin{array}{c}-.439 * * * \\
(.038)\end{array}$ \\
\hline Constant & $\begin{array}{l}.946^{* * *} \\
(.047)\end{array}$ & $\begin{array}{l}.229^{* * *} \\
(.055)\end{array}$ & $\begin{array}{c}1.655^{* * *} \\
(.179)\end{array}$ & $\begin{array}{c}1.708^{* * *} \\
(.096)\end{array}$ & $\begin{array}{c}1.861^{* * *} \\
(.195)\end{array}$ \\
\hline Year FEs & Yes & Yes & Yes & Yes & Yes \\
\hline Region FEs & Yes & Yes & Yes & Yes & Yes \\
\hline Pseudo R2 & .093 & .110 & .125 & .112 & .137 \\
\hline Log pseudolikelihood & -5921.7566 & -7151.95 & -2863.8122 & -3654.2921 & -2939.4788 \\
\hline $\mathrm{N}$ & 9,688 & 13,003 & 8,249 & 8,231 & 8,209 \\
\hline
\end{tabular}

Notes: Table entries are probit coefficients. Robust standard errors clustered at the urban-rural ara level given in parentheses. Data are weighted. ${ }^{*} p<.05^{* *} p<.01{ }^{* * *} p<.001$. 


\section{C.2 Replication with 2019 PRRI}

Table 21: Replication with 2019 PRRI

\begin{tabular}{|c|c|c|c|c|c|c|}
\hline & $\begin{array}{l}\text { Support } \\
\text { right to } \\
\text { marry }\end{array}$ & $\begin{array}{l}\text { Oppose } \\
\text { religious } \\
\text { refusals }\end{array}$ & $\begin{array}{l}\text { Support laws } \\
\text { against } \\
\text { discrimination }\end{array}$ & $\begin{array}{l}\text { Oppose } \\
\text { bathroom } \\
\text { bills }\end{array}$ & $\begin{array}{l}\text { Allow trans } \\
\text { to serve } \\
\text { in military }\end{array}$ & $\begin{array}{c}\text { Oppose ban } \\
\text { on gay } \\
\text { adoption }\end{array}$ \\
\hline \multirow{2}{*}{ Ideology (Liberal) } & $.270^{* * *}$ & $.305^{* * *}$ & $.225^{* * *}$ & $.233^{* * *}$ & $.298^{* * *}$ & $.155^{* * *}$ \\
\hline & $(.027)$ & $(.001)$ & $(.015)$ & $(.052)$ & $(.029)$ & $(.003)$ \\
\hline \multirow{2}{*}{ Black, non-Hispanic } & $-.451^{* * *}$ & .008 & $-.196^{*}$ & $.292^{* * *}$ & -.163 & $-.509^{* * *}$ \\
\hline & $(.046)$ & $(.012)$ & $(.087)$ & $(.039)$ & $(.088)$ & $(.046)$ \\
\hline \multirow{2}{*}{ Hispanic } & $-.416^{* * *}$ & $-.135^{* * *}$ & $.166^{* * *}$ & $-.305^{* * *}$ & $.283^{*}$ & $-.509^{* * *}$ \\
\hline & $(.030)$ & $(.012)$ & $(.028)$ & $(.044)$ & $(.115)$ & $(.046)$ \\
\hline \multirow{2}{*}{ Other race, non-Hispanic } & $-.452^{* * *}$ & .382 & $-.342^{* * *}$ & -.081 & .067 & .003 \\
\hline & $(.003)$ & $(.209)$ & $(.077)$ & $(.189)$ & $(.093)$ & $(.172)$ \\
\hline \multirow{2}{*}{ Age } & $-.010^{* * *}$ & $-.001^{* * *}$ & $-.005^{* *}$ & .004 & .001 & -.002 \\
\hline & $(.001)$ & $(.000)$ & $(.001)$ & $(.004)$ & $(.001)$ & $(.004)$ \\
\hline \multirow{2}{*}{ Female } & $.150^{* * *}$ & $.183^{* * *}$ & .160 & $.266^{* *}$ & .171 & $.370^{*}$ \\
\hline & $(.030)$ & $(.009)$ & $(.104)$ & $(.086)$ & $(.097)$ & $(.151)$ \\
\hline \multirow{2}{*}{ LGBT } & $.077^{*}$ & .403 & $.202^{*}$ & $.399^{* *}$ & $-.174^{* * *}$ & $.285^{* *}$ \\
\hline & $(.032)$ & $(.310)$ & $(.081)$ & $(.115)$ & $(.048)$ & $(.107)$ \\
\hline \multirow{2}{*}{ Education } & $.119^{* * *}$ & $-.121^{* *}$ & .106 & -.055 & .008 & -.008 \\
\hline & $(.002)$ & $(.036)$ & $(.066)$ & $(.047)$ & $(.028)$ & $(.007)$ \\
\hline \multirow{2}{*}{ Nonreligious } & $.564^{* * *}$ & .126 & $.045^{* * *}$ & $.463^{* * *}$ & $.199 * * *$ & $.215^{* * *}$ \\
\hline & $(.012)$ & $(.082)$ & $(.001)$ & $(.056)$ & $(.047)$ & $(.060)$ \\
\hline \multirow{2}{*}{ Nonmetro } & $-.195^{* * *}$ & $-.195^{* * *}$ & $-.367^{* * *}$ & $-.100^{* * *}$ & $-.074^{* * *}$ & $-.156^{* * *}$ \\
\hline & $(.010)$ & $(.007)$ & $(.010)$ & $(.011)$ & $(.002)$ & $(.010)$ \\
\hline \multirow{2}{*}{ Constant } & $-.307^{* * *}$ & $-.454^{* * *}$ & -.219 & -1.193 & $-.735^{* * *}$ & -.358 \\
\hline & $(.002)$ & $(.094)$ & $(.138)$ & $(.658)$ & $(.182)$ & $(.406)$ \\
\hline Pseudo R2 & .114 & .093 & .073 & .081 & .073 & .054 \\
\hline Log pseudolikelihood & -463.97992 & -503.44225 & -441.50517 & -511.16106 & -482.8601 & -485.07351 \\
\hline $\mathrm{N}^{\circ}$ & 860 & 858 & 861 & 831 & 859 & 839 \\
\hline
\end{tabular}




\section{Testing for Compositional Effects}

Table 22: 2020 CES Estimates

\begin{tabular}{|c|c|c|c|c|c|c|}
\hline & Bivariate & $\begin{array}{c}\text { with } \\
\text { sociopolitical } \\
\text { attitudes }\end{array}$ & $\begin{array}{c}\text { with } \\
\text { social } \\
\text { statuses }\end{array}$ & $\begin{array}{c}\text { with } \\
\text { demographics }\end{array}$ & $\begin{array}{l}\text { with } \\
\text { work }\end{array}$ & $\begin{array}{c}\text { with } \\
\text { sociocultural } \\
\text { beliefs }\end{array}$ \\
\hline & $.213^{* * *}$ & $.026^{*}$ & $.023^{*}$ & $.048^{* *}$ & $.047^{* *}$ & $.055^{* * *}$ \\
\hline Metro, IM+ & $(.040)$ & $(.012)$ & $(.012)$ & $(.017)$ & $(.017)$ & $(.012)$ \\
\hline & & $.160^{* * *}$ & $.105^{* * *}$ & $.184^{* * *}$ & $.184^{* * *}$ & $.178^{* * *}$ \\
\hline Party ID (Dem) & - & $(.006)$ & $(.006)$ & $(.006)$ & $(.006)$ & $(.006)$ \\
\hline Ideology (I iheral) & & $.266^{* * *}$ & $.260^{* * *}$ & $.240^{* * *}$ & $.239^{* * *}$ & $.220^{* * *}$ \\
\hline laeology (Liberal) & - & $(.010)$ & $(.010)$ & $(.009)$ & $(.009)$ & $(.009)$ \\
\hline Education & . & . & $\begin{array}{l}.031^{* *} \\
(.010)\end{array}$ & $\begin{array}{l}.010 \\
(.011)\end{array}$ & $\begin{array}{l}.003 \\
(.011)\end{array}$ & $\begin{array}{l}.016 \\
(.011)\end{array}$ \\
\hline Income & . & . & $\begin{array}{c}.001 \\
(.001)\end{array}$ & $\begin{array}{c}.016^{* * *} \\
(.002)\end{array}$ & $\begin{array}{c}.015^{* * *} \\
(.002)\end{array}$ & $\begin{array}{c}.015^{* * *} \\
(.003)\end{array}$ \\
\hline Black, non-Hispanic & . & . & . & $\begin{array}{c}-.373^{* * *} \\
(.020)\end{array}$ & $\begin{array}{l}-.371^{* * *} \\
(.020)\end{array}$ & $\begin{array}{c}-.303^{* * *} \\
(.025)\end{array}$ \\
\hline Hispanic & . & . & . & $\begin{array}{c}-.211^{* * *} \\
(.027)\end{array}$ & $\begin{array}{c}-.210^{* * *} \\
(.027)\end{array}$ & $\begin{array}{c}-.173^{* * *} \\
(.034)\end{array}$ \\
\hline Other race, non-Hispanic & . & . & . & $\begin{array}{c}-.111^{* * *} \\
(.042)\end{array}$ & $\begin{array}{l}-.109^{* *} \\
(.041)\end{array}$ & $\begin{array}{l}-.118^{* *} \\
(.042)\end{array}$ \\
\hline Age & $\cdot$ & . & . & $\begin{array}{c}-.005^{* * *} \\
(.001)\end{array}$ & $\begin{array}{c}-.005^{* * *} \\
(.001)\end{array}$ & $\begin{array}{c}-.005^{* * *} \\
(.001)\end{array}$ \\
\hline Female & - & . & · & $\begin{array}{l}.363^{* * *} \\
(.035)\end{array}$ & $\begin{array}{l}.360^{* * *} \\
(.035)\end{array}$ & $\begin{array}{l}.384^{* * *} \\
(.039)\end{array}$ \\
\hline LGBT & . & - & $\cdot$ & $\begin{array}{c}.092 \\
(.057)\end{array}$ & $\begin{array}{c}.092 \\
(.057)\end{array}$ & $\begin{array}{c}.103 \\
(.058)\end{array}$ \\
\hline Nondisclosed & $\cdot$ & $\cdot$ & · & $\begin{array}{l}-.059 \\
(.038)\end{array}$ & $\begin{array}{l}-.059 \\
(.038)\end{array}$ & $\begin{array}{l}-.070^{*} \\
(.035)\end{array}$ \\
\hline Married & - & - & . & $\begin{array}{c}-.148^{* * *} \\
(.025)\end{array}$ & $\begin{array}{l}-.148^{* * *} \\
(.0250\end{array}$ & $\begin{array}{l}-.105^{* * *} \\
(.020)\end{array}$ \\
\hline $\begin{array}{l}\text { Professional, scientific, } \\
\text { and technical }\end{array}$ & $\cdot$ & $\cdot$ & . & $\cdot$ & $\begin{array}{l}.087^{* * *} \\
(.019)\end{array}$ & $\begin{array}{l}.096^{* * *} \\
(.019)\end{array}$ \\
\hline Education & $\cdot$ & . & . & . & $\begin{array}{l}.117^{* * *} \\
(.025)\end{array}$ & $\begin{array}{l}.148^{* * *} \\
(.024)\end{array}$ \\
\hline Public adminstration & $\cdot$ & . & . & . & $\begin{array}{l}.009 \\
(.012)\end{array}$ & $\begin{array}{c}.021 \\
(.018)\end{array}$ \\
\hline Nonreligious & . & . & . & . & . & $\begin{array}{l}.192^{* * *} \\
(.031)\end{array}$ \\
\hline Frequency of attendance & . & . & . & . & . & $\begin{array}{c}-.076^{* * *} \\
(.005)\end{array}$ \\
\hline Constant & $\begin{array}{l}.277^{* * *} \\
(.040)\end{array}$ & $\begin{array}{c}-1.214^{* * *} \\
(.020)\end{array}$ & $\begin{array}{c}-1.301^{* * *} \\
(.034)\end{array}$ & $\begin{array}{c}-1.124^{* * *} \\
(.060)\end{array}$ & $\begin{array}{c}-1.105^{* * *} \\
(.060)\end{array}$ & $\begin{array}{c}-1.493^{* * *} \\
(.072)\end{array}$ \\
\hline Pseudo R2 & .005 & .218 & .218 & .241 & 241 & .257 \\
\hline Log pseudolikelihood & -38915.377 & -30551.145 & -27161.234 & -26267.917 & -26252.359 & -25063.665 \\
\hline $\mathrm{N}$ & 60,510 & 60,488 & 54,488 & 54,325 & 54,325 & 53,386 \\
\hline
\end{tabular}

Notes: Table entries are probit coefficients. Robust standard errors clustered at the urban-rural area level given in parentheses. Data are weighted. ${ }^{*} p<.05^{* *} p<.01{ }^{* * *} p<.001$. 


\section{E LGBT Population Density in Large Metro Areas and Op- position to Transgender Military Ban}

Table 23: 2020 CES Estimates

\begin{tabular}{|c|c|}
\hline & $\begin{array}{l}\text { Oppose trans } \\
\text { military ban }\end{array}$ \\
\hline LGBT population density & $\begin{array}{c}4.303^{*} \\
(1.814)\end{array}$ \\
\hline Ideology (Liberal) & $\begin{array}{l}.389 * * * \\
(.011)\end{array}$ \\
\hline Black, non-Hispanic & $\begin{array}{c}-.163^{* * *} \\
(.031)\end{array}$ \\
\hline Hispanic & $\begin{array}{c}-.160 * * * \\
(.033)\end{array}$ \\
\hline Other race, non-Hispanic & $\begin{array}{c}-.121^{* * *} \\
(.030)\end{array}$ \\
\hline Age & $\begin{array}{c}-.003^{* * *} \\
(.001)\end{array}$ \\
\hline Female & $\begin{array}{l}.366^{* * *} \\
(.019)\end{array}$ \\
\hline LGBT & $\begin{array}{l}.077^{*} \\
(.035)\end{array}$ \\
\hline Nondisclosed & $\begin{array}{l}-.001 \\
(.048)\end{array}$ \\
\hline Education & $\begin{array}{l}.045^{* * *} \\
(.008)\end{array}$ \\
\hline Nonreligious & $\begin{array}{l}.265^{* * *} \\
(.019)\end{array}$ \\
\hline Constant & $\begin{array}{c}-1.325^{* * *} \\
(.080)\end{array}$ \\
\hline Pseudo R2 & .233 \\
\hline Log pseudolikelihood & -14427.272 \\
\hline $\mathrm{N}$ & 32,420 \\
\hline
\end{tabular}

Notes: Table entries are probit coefficients. Robust standard errors clustered at the CBSA level given in parentheses. $\mathrm{N}=32,420$ respondents are nested within 55 largest metro areas of US. Data are unweighted. ${ }^{*} p<.05^{* *} p<.01{ }^{* * *} p<.001$. 


\section{F The Impact of Moving Preferences on Opposition to Fed- eral Marriage Amendment}

Table 24: 2010-2014 CCES Panel Estimates

\begin{tabular}{lc}
\hline & $\begin{array}{c}\text { Oppose federal } \\
\text { marriage } \\
\text { amendment }\end{array}$ \\
\hline Moved to metro, 1M+ & $.252^{* * *}$ \\
Left metro, 1M+ & $(.036)$ \\
Ideology (Liberal) & -.006 \\
& $(.111)$ \\
Black, non-Hispanic & $.702^{* * *}$ \\
& $(.047)$ \\
Hispanic & $-.415^{* * *}$ \\
& $(.067)$ \\
Other race, non-Hispanic & $-.158^{* *}$ \\
& $(.063)$ \\
Age & $-.208^{* *}$ \\
Female & $(.064)$ \\
& $-.006^{* *}$ \\
Education & $(.002)$ \\
& .081 \\
Nonreligious & $(.054)$ \\
\hline Constant & $.81^{* * *}$ \\
Pseudo R2 & $(.021)$ \\
Nog pseudolikelihood & $.677^{* * *}$ \\
& $(.068)$ \\
\hline
\end{tabular}

Notes: Table entries are OLS coefficients. Robust standard errors clustered by RUCC classification given in parentheses. Data are weighted. ${ }^{*} p<.05^{* *} p<.01^{* * *} p$ $<.001$. 


\section{G Exposure to Urban Environments and Support for the Right to Marty}

Table 25: Support for the Right to Marry, Conditioned by Length of Residence

\begin{tabular}{|c|c|}
\hline & $\begin{array}{l}\text { Right to } \\
\text { marry }\end{array}$ \\
\hline Ideology (Liberal) & $\begin{array}{l}.390^{* * *} \\
(.016)\end{array}$ \\
\hline Black, non-Hispanic & $\begin{array}{l}-.521^{* * *} \\
(.021)\end{array}$ \\
\hline Hispanic & $\begin{array}{l}-.085 \\
(.053)\end{array}$ \\
\hline Other race, non-Hispanic & $\begin{array}{c}-.180^{* * *} \\
(.023)\end{array}$ \\
\hline Age & $\begin{array}{c}-.007^{* * *} \\
(.001)\end{array}$ \\
\hline Female & $\begin{array}{l}.164^{* * *} \\
(.016)\end{array}$ \\
\hline LGBT & $\begin{array}{l}.641^{* * *} \\
(.054)\end{array}$ \\
\hline Nondisclosed & $\begin{array}{l}-.033 \\
(.079)\end{array}$ \\
\hline Education & $\begin{array}{l}.077^{* * *} \\
(.006)\end{array}$ \\
\hline Nonreligious & $\begin{array}{l}.536^{* * *} \\
(.012)\end{array}$ \\
\hline RUUC $x$ length of residence & \\
\hline Metro, 1M+ & $\begin{array}{l}.002^{*} \\
(.001)\end{array}$ \\
\hline Metro, 250k-1M & $\begin{array}{l}-.001 \\
(.001)\end{array}$ \\
\hline Metro, $<250 \mathrm{k}$ & $\begin{array}{l}-.003^{*} \\
(.001)\end{array}$ \\
\hline Metro adj, 20k+ & $\begin{array}{c}-.007^{* * *} \\
(.001)\end{array}$ \\
\hline Metro nonadj, 20k+ & $\begin{array}{l}-.005^{* *} \\
(.001)\end{array}$ \\
\hline Metro adj, 2.5k+ & $\begin{array}{c}-.009^{* * *} \\
(.001)\end{array}$ \\
\hline Metro nonadj, $2.5 \mathrm{k}+$ & $\begin{array}{c}-.009^{* * * *} \\
(.001)\end{array}$ \\
\hline Metro adj, $<2.5 \mathrm{k}$ & $\begin{array}{c}-.011^{* * *} \\
(.001)\end{array}$ \\
\hline Metro nonadj, $<2.5 \mathrm{k}$ & $\begin{array}{c}-.006^{* * *} \\
(.001)\end{array}$ \\
\hline Constant & $\begin{array}{c}-1.183^{* * *} \\
(.113)\end{array}$ \\
\hline Pseudo R2 & .239 \\
\hline $\begin{array}{l}\text { Log pseudolikelihood } \\
\mathrm{N}\end{array}$ & $\begin{array}{c}-27631.5 \\
54,080\end{array}$ \\
\hline
\end{tabular}




\section{H The Impact of Opposition to/Support for Federal Mar- riage Amendment on Moving Preferences}

Table 26: 2010-2014 CCES Panel Estimates

\begin{tabular}{lcc}
\hline & $\begin{array}{c}\text { Moved to } \\
\text { metro, } 1 \mathrm{M}+\end{array}$ & $\begin{array}{c}\text { Left } \\
\text { metro, } 1 \mathrm{M}+\end{array}$ \\
\hline Oppose federal marriage & $.199^{* * *}$ &. \\
amendment & $(.027)$ & .009 \\
Support federal marriage &. & $.071)$ \\
amendment & $-.072^{* *}$ & .066 \\
Ideology (Liberal) & $(.021)$ & $(.182)$ \\
& $-.164^{*}$ & -.070 \\
Black, non-Hispanic & $(.081)$ & $(.400)$ \\
& $.179^{*}$ & .081 \\
Hispanic & $(.082)$ & $(.156)$ \\
& $.223^{* * *}$ & $-.602^{*}$ \\
Other race, non-Hispanic & $(.052)$ & $(.248)$ \\
& $-.009^{* * *}$ & -.004 \\
Age & $(.001)$ & $(.002)$ \\
& $-.217^{* * *}$ & $.358^{* * *}$ \\
Female & $(.018)$ & $(.117)$ \\
& $.106^{* * *}$ & $.193^{* * *}$ \\
Education & $(.004)$ & $(.039)$ \\
& $.214^{* * *}$ & .016 \\
Nonreligious & $(.034)$ & $(.059)$ \\
\hline Constant & $-2.556^{* * *}$ & -2.739 \\
& $(.217)$ & $(.597)$ \\
\hline Pseudo R2 & .068 & .085 \\
Log pseudolikelihood & -589.88681 & -627.48017 \\
$\mathrm{~N}$ & 9,455 & 9,455 \\
\hline
\end{tabular}

Notes: Table entries are probit coefficients. Robust standard errors clustered by RUCC classification given in parentheses. Data are weighted. ${ }^{*} p<.05^{* *} p<.01^{* * *} p<.001$. 